\title{
Thermodynamic modeling of the Sr-Co-Fe-O system
}

\author{
Zhang, Wei Wei; Povoden-Karadeniz, Erwin; Chen, Ming; Hendriksen, Peter Vang
}

Published in:

Solid State lonics

Link to article, DOI:

10.1016/j.ssi.2016.05.011

Publication date:

2016

Document Version

Peer reviewed version

Link back to DTU Orbit

Citation (APA):

Zhang, W. W., Povoden-Karadeniz, E., Chen, M., \& Hendriksen, P. V. (2016). Thermodynamic modeling of the Sr-Co-Fe-O system. Solid State lonics, 292, 88-97. https://doi.org/10.1016/j.ssi.2016.05.011

\section{General rights}

Copyright and moral rights for the publications made accessible in the public portal are retained by the authors and/or other copyright owners and it is a condition of accessing publications that users recognise and abide by the legal requirements associated with these rights.

- Users may download and print one copy of any publication from the public portal for the purpose of private study or research.

- You may not further distribute the material or use it for any profit-making activity or commercial gain

- You may freely distribute the URL identifying the publication in the public portal

If you believe that this document breaches copyright please contact us providing details, and we will remove access to the work immediately and investigate your claim. 


\title{
Thermodynamic Modeling of the Sr-Co-Fe-O System
}

\author{
Wei-Wei Zhang a ${ }^{\text {a }}$ Ming Chen ${ }^{\mathrm{a},{ }^{*} \text {, Erwin Povoden-Karadeniz }}{ }^{\mathrm{b}}$, Peter Vang Hendriksen ${ }^{\mathrm{a}}$ \\ a Department of Energy Conversion and Storage, Technical University of Denmark, DK-4000 Roskilde, \\ Denmark \\ ${ }^{b}$ Institute of Materials Science and Technology, Vienna University of Technology, 1040 Vienna, Austria \\ *Corresponding author: minc@dtu.dk,Tel.: +45 46775757,Fax:+4546775858
}

\begin{abstract}
This paper reviews and assesses phase equilibria and thermodynamic properties of phases in the $\mathrm{Sr}-\mathrm{Co}-\mathrm{Fe}-\mathrm{O}$ system, with a focus on oxides, especially the $\mathrm{SrCo}_{1-x} \mathrm{Fe}_{x} \mathrm{O}_{3-\delta}$ perovskite. In our work, the $\mathrm{SrCo}_{1-x} \mathrm{Fe}_{x} \mathrm{O}_{3-\delta}$ perovskite was modeled with a three-sublattice model, where the three sublattices correspond to the A, B and oxygen sites in an $\mathrm{ABO}_{3}$ perovskite, respectively. A number of other important ternary oxide phases in Sr-Co-O and $\mathrm{Sr}-\mathrm{Co}-\mathrm{Fe}-\mathrm{O}$ were also considered. Available thermodynamic and phase diagram data were carefully assessed. A thermodynamic description of Sr-Co-O was derived using the CALPHAD approach and was further extrapolated to that of $\mathrm{Sr}-\mathrm{Co}-\mathrm{Fe}-\mathrm{O}$. The thermodynamic database of $\mathrm{Sr}-\mathrm{Co}-\mathrm{Fe}-\mathrm{O}$ established in this work allows for calculating phase diagrams, thermodynamic properties, cation distribution and defect chemistry properties, and therefore enables material composition optimization for various applications, including solid oxide fuel cells and oxygen membranes.
\end{abstract}

Key words: strontium cobaltite, phase diagram, perovskite.

\section{Introduction}

Strontium cobaltites offer good electronic and ionic conductivities that enable their application in solid oxide fuel cells (SOFCs) and oxygen permeation membranes [1]. $\mathrm{Sr}_{3} \mathrm{Fe}_{2-x} \mathrm{Co}_{x} \mathrm{O}_{7-\delta}$ and $\mathrm{SrCo}_{1-x} \mathrm{Fe}_{x} \mathrm{O}_{3-\delta}$ in $\mathrm{Sr}-\mathrm{Co}-\mathrm{Fe}-\mathrm{O}$ have also received special attention due to their magnetic properties, notably the magnetoresistance (MR) effect $[2,3]$. Both the magnetic and the electrical properties of these oxides depend strongly on composition and preparation methods [4]. Though extensive studies have been carried out on the effect of composition and sample preparation on the structure and physical properties of the oxides in $\mathrm{Sr}-\mathrm{Co}-\mathrm{Fe}-\mathrm{O}$, the phase relationship and thermodynamic properties have not been well established.

In this research, thermodynamic databases of $\mathrm{Sr}-\mathrm{Co}-\mathrm{O}$ and $\mathrm{Sr}-\mathrm{Co}-\mathrm{Fe}-\mathrm{O}$ were developed as part of our project to develop a thermodynamic database of $\mathrm{La}-\mathrm{Sr}-\mathrm{Co}-\mathrm{Fe}-\mathrm{O}$ for SOFC applications [5-7]. The literature data available on $\mathrm{Sr}-\mathrm{Co}-\mathrm{O}$ and $\mathrm{Sr}-\mathrm{Co}-\mathrm{Fe}-\mathrm{O}$ were carefully reviewed. A thermodynamic description of $\mathrm{Sr}-\mathrm{Co}-\mathrm{O}$ was derived using the CALculation of PHAse Diagrams (CALPHAD) approach and was combined with a description of Sr-Fe-O developed by Povoden-Karadeniz et al. [8] and further extrapolated to Sr-Co-Fe-O. Various phase diagrams and thermodynamic properties were calculated and then compared with experimental data reported in the literature. The potential applications of the new database were examined. 


\section{Literature review}

The Sr-Co-Fe-O system contains the following binary oxides: $\mathrm{SrO}, \mathrm{SrO}_{2}, \mathrm{CoO}, \mathrm{Co}_{3} \mathrm{O}_{4}, \mathrm{FeO}, \mathrm{Fe}_{2} \mathrm{O}_{3}$ and $\mathrm{Fe}_{3} \mathrm{O}_{4}$. Detailed information on the binary oxides can be found in previous modeling work [9-11]. There are five ternary oxides in $\mathrm{Sr}-\mathrm{Fe}-\mathrm{O}$ : $\mathrm{SrFeO}_{3-\delta}, \mathrm{Sr}_{2} \mathrm{FeO}_{4-\delta}, \mathrm{Sr}_{4} \mathrm{Fe}_{3} \mathrm{O}_{10-\delta}, \mathrm{Sr}_{3} \mathrm{Fe}_{2} \mathrm{O}_{7-\delta}, \mathrm{Sr}_{4} \mathrm{Fe}_{6} \mathrm{O}_{13-\delta}$ [8]. Two ternary oxides have been reported in $\mathrm{Co}-\mathrm{Fe}-\mathrm{O}$ : halite $\left(\mathrm{Co}_{x} \mathrm{Fe}_{1-x} \mathrm{O}\right)$ and spinel $\left(\mathrm{Co}_{x} \mathrm{Fe}_{3-x} \mathrm{O}_{4}\right)$ [12]. The reported ternary and quaternary solid oxide phases for Sr-Co-O and $\mathrm{Sr}-\mathrm{Co}-\mathrm{Fe}-\mathrm{O}$ were reviewed in this research. Below is a short summary of results from the relevant literature.

\section{1. $\mathrm{Sr}-\mathrm{Co}-\mathrm{O}$}

Previous studies of phase equilibria in $\mathrm{Sr}-\mathrm{Co}-\mathrm{O}$ have focused on compositions related to the perovskite phase. The stability of other oxide phases, such as the Ruddlesden-Popper phase $\left(\mathrm{Sr}_{3} \mathrm{Co}_{2} \mathrm{O}_{7-\delta}\right)$, has not been fully studied. Takeda et al. [13] investigated phase relations in Sr-Co-O. They studied phase composition as a function of temperature in various atmospheres using X-ray diffraction (XRD), thermogravimetry (TG), and differential thermal analysis (DTA). They reported the stability ranges of cubic perovskite, brownmillerite and structure undefined low temperature phases. Rodriguez et al. [14] studied phase transition in $\mathrm{Sr}_{2} \mathrm{Co}_{2} \mathrm{O}_{5}$ using neutron powder diffraction in an atmosphere of $\mathrm{PO}_{2} \approx 10^{-4}$ bar with continuously changing temperature. They were unable to correctly identify the low temperature phases [15]. Vashook et al. [16, 17] explored phase transformation temperatures for strontium cobaltite $\left(\mathrm{SrCoO}_{x}\right)$ in a $\mathrm{PO}_{2}$ range of $50-400 \mathrm{~Pa}$ using XRD and TG. The stability regions for cubic perovskite, brownmillerite and low temperature phases $\left(\mathrm{Sr}_{6} \mathrm{Co}_{5} \mathrm{O}_{15}\right)$ at low $P \mathrm{O}_{2}$ were determined. They described the transformation from cubic perovskite to brownmillerite as second-order and the one from brownmillerite to $\mathrm{Sr}_{6} \mathrm{Co}_{5} \mathrm{O}_{15}$ and $\mathrm{Co}_{3} \mathrm{O}_{4}$ as first-order.

\subsection{1. $\mathrm{SrCoO}_{3-\delta}$}

$\mathrm{SrCoO}_{3-\delta}$ is a fully disordered oxygen-deficient cubic perovskite phase with $P m 3 m$ symmetry. The stoichiometric $\mathrm{SrCoO}_{3}$ can be synthesized only under high oxygen partial pressure (>2000 bar) [13, 18]. $\mathrm{SrCoO}_{3-\delta}$ has been extensively studied due to its attractive magnetic [18, 19] and electric properties [19] and its oxygen mobility [20]. Taguchi et al. [18] investigated the effect of oxygen deficiency on the magnetic properties of $\mathrm{SrCoO}_{3-\delta}(0<\delta<0.5)$. They found a strong dependence of the Curie temperature on the oxygen deficiency. They determined the $\mathrm{Co}^{4+}$ content at low temperatures $(<623 \mathrm{~K})$ and high oxygen pressures $(50-2600$ bar $)$ assuming the presence of $\mathrm{Co}^{4+}$ and $\mathrm{Co}^{3+}$ only. Nakatsuka et al. [20] prepared a single crystal $\mathrm{SrCoO}_{3-\delta}$ at high temperature in an $\mathrm{O}_{2}$ gas flow and reported the average Co valency as +3.28 using XRD. $\mathrm{Co}^{3+}$ and $\mathrm{Co}^{4+}$ ions coexist in the oxygen-deficient $\mathrm{SrCoO}_{3-x}$ cubic perovskite. Takeda et al. [13] investigated the stability of $\mathrm{SrCoO}_{3-\delta}$ at a few chosen temperatures and atmospheres. Rodriguez et al. [14] reported the transformation temperature from $\mathrm{SrCoO}_{3-\delta}$ to $\mathrm{Sr}_{2} \mathrm{Co}_{2} \mathrm{O}_{5}$ as $1113 \mathrm{~K}$ at $\mathrm{PO}_{2} \approx 10^{-4}$ bar. Vashook et al. [16] determined the stability range of $\mathrm{SrCoO}_{3-\delta}$ at various temperatures using DTA and XRD. They $[17,21]$ further investigated the oxygen nonstoichiometry and electrical conductivity of $\mathrm{SrCoO}_{3-\delta}$ in a temperature range of $1223-1323 \mathrm{~K}$ and an oxygen partial pressure range of $10^{-5}-10^{-2}$ bar by solid electrolyte coulometry and resistivity measurements. They reported a large decrease in resistivity accompanying with the transition from $\mathrm{Sr}_{6} \mathrm{Co}_{5} \mathrm{O}_{15}$ to $\mathrm{SrCoO}_{3-\delta}$. Le Toquin et al. [22] investigated crystal structure evolution from $\mathrm{SrCoO}_{2.5}$ to $\mathrm{SrCoO}_{3}$ in situ by neutron diffraction as well as by X-ray absorption fine structure (XAFS) spectroscopy. From the neutron diffraction experiments, the structure of two intermediate phases, $\mathrm{SrCoO}_{2.75}$ and $\mathrm{SrCoO}_{2.82 \pm 0.07}$, were characterized. Calle-Vallejo et al. [23] reported the Gibbs energy of formation for $\mathrm{SrCoO}_{3}$ as $-163 \mathrm{~kJ} / \mathrm{mol}$ at $298 \mathrm{~K}$ obtained from first-principle calculations.

\subsection{2. $\mathrm{Sr}_{2} \mathrm{Co}_{2} \mathrm{O}_{5}$}


$\mathrm{Sr}_{2} \mathrm{Co}_{2} \mathrm{O}_{5}$ has a brownmillerite-type structure, which is a close relative of the perovskite structure with ordering of vacancies. Grenier et al. [24] investigated the crystal structure of $\mathrm{Sr}_{2} \mathrm{Co}_{2} \mathrm{O}_{5}$ at $1183-1373 \mathrm{~K}$ and found that, on cooling, it undergoes an exothermic reaction and transforms into a hexagonal phase at $1183 \mathrm{~K}$ Takeda et al. [13] reported that $\mathrm{Sr}_{2} \mathrm{Co}_{2} \mathrm{O}_{5}$ is stable in a narrow temperature range at around $1073-1273 \mathrm{~K}^{\text {in }} \mathrm{N}_{2}$. With increasing temperature, it transforms into the $\mathrm{SrCoO}_{3-\delta}$ perovskite phase at about $1373 \mathrm{~K}$ in $\mathrm{N}_{2}$. They also found ordered oxygen vacancies in $\mathrm{Sr}_{2} \mathrm{Co}_{2} \mathrm{O}_{5-\delta}(\delta=0.04-0.16)$. No Fe solubility in $\mathrm{Sr}_{2} \mathrm{Co}_{2} \mathrm{O}_{5}$ was reported. Saal [25] determined the Gibbs energy of $\mathrm{Sr}_{2} \mathrm{Co}_{2} \mathrm{O}_{5}$ obtained via first-principle calculations.

\subsection{3. $\mathrm{Sr}_{6} \mathrm{Co}_{5} \mathrm{O}_{15}$}

$\mathrm{Sr}_{6} \mathrm{Co}_{5} \mathrm{O}_{15}$ has previously been described as a low-temperature rhombohedral/hexagonal form of $\mathrm{Sr}_{2} \mathrm{Co}_{2} \mathrm{O}_{5}$ $[24,26,27]$. Takeda et al. [13] propose that it is cobalt-deficient $2 \mathrm{H}-\mathrm{SrCo}_{1-x} \mathrm{O}_{y}(x \approx 0.1)$. Harrison et al. [15] were the first to confirm the existence of $\mathrm{Sr}_{6} \mathrm{Co}_{5} \mathrm{O}_{15}$ with a stoichiometric composition and $\mathrm{Sr}_{6} \mathrm{Co}_{5} \mathrm{O}_{15}$ is a $2 \mathrm{H}$ hexagonal-type phase. When high temperature brownmillerite $\mathrm{Sr}_{2} \mathrm{Co}_{2} \mathrm{O}_{5}$ cools in air, it decomposes into a twophase mixture of $\mathrm{Sr}_{6} \mathrm{Co}_{5} \mathrm{O}_{15}$ and $\mathrm{CoO}_{x}$ [15]. No Fe solubility in $\mathrm{Sr}_{6} \mathrm{Co}_{5} \mathrm{O}_{15}$ is reported in the literature. Its crystallographic, magnetic, and electronic properties have been extensively studied by Sun et al. and Iwasaki et al. $[28,29]$. No experimental study was carried out on the thermodynamic properties of $\mathrm{Sr}_{6} \mathrm{Co}_{5} \mathrm{O}_{15}$. Saal et al. [30] reported on its heat capacity and entropy up to $1300 \mathrm{~K}$ from first-principle calculations using the DebyeGrüneisen model and derived the Gibbs energy function for $\mathrm{Sr}_{6} \mathrm{Co}_{5} \mathrm{O}_{15}$.

A few other strontium cobaltites with a hexagonal perovskite-like structure have been reported, with a Co content of 42.8 - 44.5 cation\% (cat.\%), including $\mathrm{Sr}_{24} \mathrm{Co}_{19} \mathrm{O}_{57}, \mathrm{Sr}_{14} \mathrm{Co}_{11} \mathrm{O}_{33}, \mathrm{Sr}_{4} \mathrm{Co}_{3} \mathrm{O}_{9}$ and $\mathrm{Sr}_{5} \mathrm{Co}_{4} \mathrm{O}_{12}$ [31-33]. The existence of $\mathrm{Sr}_{24} \mathrm{Co}_{19} \mathrm{O}_{57}$ and $\mathrm{Sr}_{14} \mathrm{Co}_{11} \mathrm{O}_{33}$ has been denied by $\mathrm{Li}$ et al. and Aksenova et al. [32, 34]. The reported $\mathrm{Sr}_{4} \mathrm{Co}_{3} \mathrm{O}_{9}$ and $\mathrm{Sr}_{5} \mathrm{Co}_{4} \mathrm{O}_{12}$ have XRD patterns and stability ranges similar to those of $\mathrm{Sr}_{6} \mathrm{Co}_{5} \mathrm{O}_{15}$ [33]. The existence of $\mathrm{Sr}_{4} \mathrm{Co}_{3} \mathrm{O}_{9}$ and $\mathrm{Sr}_{5} \mathrm{Co}_{4} \mathrm{O}_{12}$ is doubtable and further verified in this work.

\subsection{4. $\mathrm{Sr}_{3} \mathrm{Co}_{2} \mathrm{O}_{7-\delta}$}

$\mathrm{Sr}_{3} \mathrm{Co}_{2} \mathrm{O}_{7-\delta}$ is an oxygen-deficient Ruddlesden-Popper type phase. Its crystal structure was characterized by Dann and Weller [35] using X-ray and neutron diffraction and was reported as orthorhombic-type. They indicated that this phase can be obtained at high temperatures $(1273-1473 \mathrm{~K})$ and ambient pressure. At low temperatures and/or high $\mathrm{PO}_{2}, \mathrm{Sr}_{3} \mathrm{Co}_{2} \mathrm{O}_{7-\delta}$ decomposes into a mixture of $\mathrm{Sr}_{6} \mathrm{Co}_{5} \mathrm{O}_{15}, \mathrm{SrCoO}_{3-\delta}$ and $\mathrm{SrO}$. The oxygen deficiency $\left(\delta\right.$ in $\mathrm{Sr}_{3} \mathrm{Co}_{2} \mathrm{O}_{7-\delta}$ ) was reported to be around $1 \pm 0.2$, corresponding to an average Co oxidation state of around $+3 \pm 0.2$. The crystal structure and magnetic property of this phase have been reported in various studies [36-38]. It is possible to synthesize other Ruddlesden-Popper type phases $\left(\mathrm{Sr}_{n+1} \mathrm{Co}_{n} \mathrm{O}_{3 n+1}, \mathrm{n} \leq 4\right)$ under $6 \mathrm{GPa}$ at 1273 - $1773 \mathrm{~K}$ [39]. However, they are not stable under ambient conditions.

\section{2. $\mathrm{Sr}-\mathrm{Co}-\mathrm{Fe}-\mathrm{O}$}

The phase diagram data for the Sr-Co-Fe-O system are rather limited. Aksenova et al. [34] studied the phase equilibria in the $\mathrm{Sr}-\mathrm{Co}-\mathrm{Fe}-\mathrm{O}$ system at $1373 \mathrm{~K}$ in air using 68 samples with various compositions. They determined the stability region and crystal structure of solid solutions in the Sr-Co-Fe-O system using XRD and further constructed a $1373 \mathrm{~K}$ isothermal section of $\mathrm{SrO}-\mathrm{CoO}-\mathrm{Fe}_{2} \mathrm{O}_{3}$ in air. Fossdal et al. [40] studied the $\mathrm{Sr}_{4} \mathrm{Fe}_{6-x} \mathrm{Co}_{x} \mathrm{O}_{13-\delta}$ phase in the range of $1048-1493 \mathrm{~K}$ using XRD and DTA and provided a Fe rich part of the isothermal section of $\mathrm{SrO}-\mathrm{CoO}-\mathrm{Fe}_{2} \mathrm{O}_{3}$ at $1173 \mathrm{~K}$ in air.

\subsection{1. $\mathrm{SrCo}_{1-x} \mathrm{Fe}_{x} \mathrm{O}_{3-\delta}$}


$\mathrm{SrFeO}_{3-\delta}$ has a tetragonal perovskite type structure. By substituting Fe with $\mathrm{Co}$, the crystal structure changes from tetragonal to cubic [34, 41]. Aksenova et al. [34] determined the stability range of $\mathrm{SrCo}_{1-x} \mathrm{Fe}_{x} \mathrm{O}_{3-\delta}$ by XRD and reported that the perovskite phase is stable within the range of $0 \leq x \leq 0.7$ at $1373 \mathrm{~K}$ in air. The oxygen nonstoichiometry and phase stability of $\mathrm{SrCo}_{1-x} \mathrm{Fe}_{x} \mathrm{O}_{3-\delta}$ have been studied by a number of groups [42-46], focusing on the composition $\mathrm{SrCo}_{0.8} \mathrm{Fe}_{0.2} \mathrm{O}_{3-\delta}$. Liu et al. [43] studied the temperature range of $823-1263 \mathrm{~K}$ and $P \mathrm{O}_{2}=$ 0.015 - 1 bar using TG and XRD, while Grunbaum et al. [44] chose a temperature interval of $823-1223 \mathrm{~K}$ and $P_{2}=10^{-5}-1$ bar using TG and high temperature XRD (HT-XRD). Moreover, McIntosh et al. [45] investigated the stability of $\mathrm{SrCo}_{0.8} \mathrm{Fe}_{0.2} \mathrm{O}_{3-\delta}$ at $T=873-1173 \mathrm{~K}$ and $P \mathrm{O}_{2}=5 \times 10^{-4}-1$ bar using in situ neutron diffraction. Depending on temperature and oxygen partial pressure, $\mathrm{SrCo}_{0.8} \mathrm{Fe}_{0.2} \mathrm{O}_{3-\delta}$ is either a single phase perovskite or a two-phase mixture of perovskite and brownmillerite. The cubic $\mathrm{SrCo}_{0.8} \mathrm{Fe}_{0.2} \mathrm{O}_{3-\delta}$ perovskite single phase is stable at $T>1073 \mathrm{~K}$ and $P_{2}=10^{-5}-1$ bar and its stability range extends to lower temperatures with increasing oxygen partial pressure. However, the stability range determined for $\mathrm{SrCo}_{0.8} \mathrm{Fe}_{0.2} \mathrm{O}_{3-\delta}$ from these studies is unreliable, because the samples used were most likely not equilibrated due to short $(<24 \mathrm{~h})$ annealing time. Moreover, they were unable to distinguish the hexagonal $\mathrm{Sr}_{6} \mathrm{Co}_{5} \mathrm{O}_{15}$ phase from the $\mathrm{SrCo}_{1-x} \mathrm{Fe}_{x} \mathrm{O}_{3-\delta}$ perovskite and $\mathrm{Sr}_{2} \mathrm{Co}_{2} \mathrm{O}_{5}$ brownmillerite phases. McIntosh et al. [45, 46] measured the oxygen non-stoichiometry of $\mathrm{SrCo}_{1-x} \mathrm{Fe}_{x} \mathrm{O}_{3-\delta}$ using TG and DTA, but the results among these two studies were inconsistent.

Mitchell et al. [47] investigated the stability of $\mathrm{SrCo}_{0.2} \mathrm{Fe}_{0.8} \mathrm{O}_{3-\delta}$ at $1173 \mathrm{~K}$ and $P \mathrm{O}_{2}=10^{-0.67}-10^{-13.3}$ bar, and found that it is stable for the entire $\mathrm{PO}_{2}$ range. Vashuk et al. [48] studied the oxygen non-stoichiometry and defect chemistry of $\mathrm{SrCo}_{0.25} \mathrm{Fe}_{0.75} \mathrm{O}_{3-\delta}$ using solid-electrolyte coulometry, TG, and conductivity measurements at $573-1273 \mathrm{~K}$ and $\mathrm{PO}_{2}=10^{-4}-1$ bar. $\mathrm{SrCo}_{0.25} \mathrm{Fe}_{0.75} \mathrm{O}_{3-\delta}$ was shown to be p-type throughout the entire experimental oxygen partial pressure and temperature range. Perovskite to brownmillerite phase transformation was reported.

\subsubsection{Solid solution $\mathrm{Sr}_{3} \mathrm{Fe}_{2-x} \mathrm{Co}_{x} \mathrm{O}_{7-\delta}$}

The electronic, magnetic and magneto-resistance properties of $\mathrm{Sr}_{3} \mathrm{Fe}_{2-x} \mathrm{Co}_{x} \mathrm{O}_{7-\delta}$ were studied by Veith et al. [2]. They reported that single-phase $\mathrm{Sr}_{3} \mathrm{Fe}_{2-x} \mathrm{Co}_{x} \mathrm{O}_{7-\delta}$ exists in a composition range of $0.25 \leq x \leq 1.75$ at $1273 \mathrm{~K}$ under flowing $\mathrm{O}_{2}$. Aksenova et al. [34] reported single phase $\mathrm{Sr}_{3} \mathrm{Fe}_{2-x} \mathrm{Co}_{x} \mathrm{O}_{7-\delta}$ at $1373 \mathrm{~K}$ in air $(0 \leq x \leq 0.4)$. At $x$ $>0.4$, they detected formation of $\mathrm{Sr}_{3} \mathrm{Co}_{2} \mathrm{O}_{7-\delta}$.

\subsubsection{Solid solution $\mathrm{Sr}_{4} \mathrm{Fe}_{6-x} \mathrm{Co}_{x} \mathrm{O}_{13-\delta}$}

The $\mathrm{Sr}_{4} \mathrm{Fe}_{6-x} \mathrm{Co}_{x} \mathrm{O}_{13-\delta}$ solid solution has an orthorhombic structure (space group Iba2) [49, 50]. The phase stability of $\mathrm{Sr}_{4} \mathrm{Fe}_{6-} \mathrm{Co}_{x} \mathrm{O}_{13-\delta}$ and its electrical conductivity and oxygen permeability have been investigated by a number of groups. A certain amount of $\mathrm{Co}$ can be dissolved in $\mathrm{Sr}_{4} \mathrm{Fe}_{6-x} \mathrm{Co}_{x} \mathrm{O}_{13-\delta}$ without forming a secondary phase. Beyond the solubility limit, the $\mathrm{Sr}_{4} \mathrm{Fe}_{6-x} \mathrm{Co}_{x} \mathrm{O}_{13-\delta}$ single phase is replaced by a three-phase mixture of $\mathrm{Sr}_{4} \mathrm{Fe}_{6-x} \mathrm{Co}_{x} \mathrm{O}_{13-\delta}, \mathrm{SrCo}_{1-x} \mathrm{Fe}_{x} \mathrm{O}_{3-\delta}$ and $\mathrm{Co}_{x} \mathrm{Fe}_{1-x} \mathrm{O}$ or $\mathrm{Co}_{x} \mathrm{Fe}_{3-x} \mathrm{O}_{4}$ [50-52]. Co in $\mathrm{Sr}_{4} \mathrm{Fe}_{6-x} \mathrm{Co}_{x} \mathrm{O}_{13-\delta}$ affects not only the phase stability but also the oxygen permeability and electrical conductivity. Both oxygen permeability and electrical conductivity increase with increasing $x$ in either the single phase region or the three-phase region [51-53]. Various solubility limits of $\mathrm{Co}$ in $\mathrm{Sr}_{4} \mathrm{Fe}_{6-x} \mathrm{Co}_{x} \mathrm{O}_{13-\delta}$ have been reported. Xia et al. [50] reported a maximum Co solubility corresponding to $x=1.8$ at $1273 \mathrm{~K}$. The solubility decreases with increasing temperature in the range $1273-1373 \mathrm{~K}$. Armstrong et al. [53] reported a Co solubility limit of $x=1.5$ in $\mathrm{Sr}_{4} \mathrm{Fe}_{6-x} \mathrm{Co}_{x} \mathrm{O}_{13-\delta}$ at $1273 \mathrm{~K}$. Deng et al. [52] determined $x=1.5$ in samples slowly cooled from $1473 \mathrm{~K}$. They reported an average valence state of $\mathrm{Co}$ and $\mathrm{Fe}$ as around $2.9 \sim 3.0$. Moreover, values of $x=1.4, \sim 1.6,1.6$ were reported by Kim et al. [54] in samples sintered at $1423 \mathrm{~K}$, by Ma et al. [51] in samples sintered at $1473 \mathrm{~K}$, and by Aksenova et al. [34] in samples sintered at $1373 \mathrm{~K}$, respectively. Fossdal et al. [40] systemically measured the Co solubility in $\mathrm{Sr}_{4} \mathrm{Fe}_{6-x} \mathrm{Co}_{x} \mathrm{O}_{13-\delta}$ at several temperatures. They concluded that $\mathrm{Sr}_{4} \mathrm{Fe}_{6-x} \mathrm{Co}_{x} \mathrm{O}_{13-\delta}$ is stable only in a narrow temperature range of 1048-1493 K. The highest Co solubility was obtained in samples sintered at $1173 \mathrm{~K}$, and 
the maximum Co-content was close to $\mathrm{Sr}_{4} \mathrm{Fe}_{4} \mathrm{Co}_{2} \mathrm{O}_{13}$. At higher or lower sintering temperatures, Co solubility decreases. This scattering of experimental Co solubility limits is probably due to the slow reaction kinetics for the transition between the single phase $\mathrm{Sr}_{4} \mathrm{Fe}_{6-x} \mathrm{Co}_{x} \mathrm{O}_{13-\delta}$ and the three-phase mixture of $\mathrm{Sr}_{4} \mathrm{Fe}_{6-x} \mathrm{Co}_{x} \mathrm{O}_{13-\delta}$, $\mathrm{SrFe}_{1-x} \mathrm{Co}_{x} \mathrm{O}_{3-\delta}$ and $\mathrm{Co}_{x} \mathrm{Fe}_{1-x} \mathrm{O}$ or $\mathrm{Co}_{x} \mathrm{Fe}_{3-x} \mathrm{O}_{4}$ during heating or cooling [40].

\subsubsection{Other ternary oxides}

For the other ternary oxides, no solubility of a third cation has been reported, e.g. no solubility of $\mathrm{Sr}$ in $\mathrm{Co}_{x} \mathrm{Fe}_{1-x} \mathrm{O}_{1+\delta}$ or in $\mathrm{Co}_{x} \mathrm{Fe}_{3-x} \mathrm{O}_{4}$ and no Co solubility in $\mathrm{SrFe}_{12} \mathrm{O}_{19-\delta}$.

\section{Thermodynamic modeling}

The new thermodynamic description of Sr-Co-O presented here provides descriptions of all observed equilibrium phases. The model description of the perovskite phase solves a problem of too high entropy at high temperatures assessed by Saal [25]. Our database is based on thermodynamic descriptions of the sub-systems Sr$\mathrm{O}$ (by Risold et al. [9]) and Co-O (by Chen et al. [10]) and extended to Sr-Co-Fe-O by adopting recent descriptions of Sr-Fe-O by Povoden-Karadeniz [8] and of Co-Fe-O by Zhang and Chen [12]. Compound Energy Formalism (CEF) [55], which is widely used in CALPHAD assessments, was employed for modeling the Gibbs energy for all the phases in Sr-Co-Fe-O. The lattice stability for pure elements was adopted from Dinsdale [56]. The models used for the oxide phases in Sr-Co-O and Sr-Co-Fe-O are described in detail in the following sections. Table 1 provides meanings of the physical variables included in the model descriptions.

Table 1 Nomenclature

\begin{tabular}{|l|l|l|l|}
\hline$T$ & Absolute temperature, $\mathrm{K}$ & ${ }^{o} G_{A: B}^{\theta}$ & $\begin{array}{l}\text { Gibbs energy of phase } \theta \text { with constituent A } \\
\text { occupying the first sublattice and B the second } \\
\text { sublattice. }\end{array}$ \\
\hline$R$ & Gas constant, 8.31451 $\mathrm{J} \mathrm{mol}^{-1} \mathrm{~K}^{-1}$ & $y_{i}$ & Site fraction of constituent $i$ \\
\hline$G_{m}^{\theta}$ & Gibbs energy of phase $\theta$ per mole component & $H_{A}^{S E R}$ & $\begin{array}{l}\text { Stable element reference (SER): reference state } \\
\text { for pure element A at 298.15 K and } 1 \text { atm. }\end{array}$ \\
\hline${ }^{E} G_{m}^{\theta}$ & $\begin{array}{l}\text { Excess Gibbs energy of phase } \theta \text { per mole component. } \\
\text { The excess Gibbs energy accounts for contributions } \\
\text { due to non-ideal interaction between the components. }\end{array}$ & $L_{i_{m}, i_{n}: j}^{\theta}$ & $\begin{array}{l}\text { Interaction parameter for the } \theta \text { phase, accounting } \\
\text { for the non-ideal interaction between the } \\
\text { constituents } i_{m} \text { and } i_{n} \text { on the first sublattice with } \\
\text { the constituent } j \text { on the second sublattice. }\end{array}$ \\
\hline
\end{tabular}

\subsection{Liquid}

The description for the liquid phase was ideally extrapolated from the ionic two-sublattice modeling [57, 58] of the subsystems ( $\mathrm{Sr}-\mathrm{O}$ [9], $\mathrm{Co}-\mathrm{O}$ [10] and Fe-O [11]). The ionic liquid model assumes that cations occupy one sublattice and anions occupy the other. Hypothetical vacancies are introduced on the anion sublattice in order to extend the description to a liquid with only cations (i.e. a metallic liquid). Further detail on the model can be found in the paper by Hillert et al. [57] and Sundman [58]. In the current work, the liquid phase in Sr-Co-Fe-O is described as:

$$
\left(\mathrm{Co}^{2+}, \mathrm{Co}^{3+}, \mathrm{Fe}^{2+}, \mathrm{Fe}^{3+}, \mathrm{Sr}^{2+}\right)_{p}\left(\mathrm{O}^{2-}, \mathrm{Va}^{\mathrm{q}^{-}}\right)_{q}
$$

where $\mathrm{Va}^{\mathrm{q}^{-}}$represents hypothetical vacancies with a valency corresponding to the average for the cations on the other sublattice, 


$$
\begin{aligned}
& p=2 \mathrm{yo}^{2-}+q \mathrm{y}_{\mathrm{Va}} \\
& q=2 \mathrm{y}_{\mathrm{Co}}^{2+}+3 \mathrm{y}_{\mathrm{Co}}^{3+}+2 \mathrm{y}_{\mathrm{Fe}}{ }^{2+}+3 \mathrm{yFe}^{3+}+2 \mathrm{ySr}^{2+}
\end{aligned}
$$

The Gibbs energy of the liquid phase is expressed as:

$$
G_{m}^{L}=q \sum_{i} y_{i} y_{V a}{ }^{o} G_{i: V a}^{L}+\sum_{i} y_{i} y_{O^{2-}}{ }^{o} G_{i: O^{2-}}^{L}+p R T \sum_{i} y_{i} \ln y_{i}+q R T \sum_{j} y_{j} \ln y_{j}+{ }^{E} G_{m}^{L}
$$

where $i$ represents the constituents in the first sublattice, $j$ represents the constituents in the second sublattice. The excess Gibbs energy ${ }^{E} G_{m}^{L}$ is formulated as:

$$
{ }^{E} G_{m}^{L}=\sum_{i_{m}} \sum_{i_{n} \neq i_{m}} y_{i_{m}} y_{i_{n}}\left(y_{O^{2-}} L_{i_{m}, i_{n}: O^{2-}}^{L}+q y_{V a}^{2} L_{i_{m}, i_{n}: V a}^{L}\right)+\sum_{i_{m}} y_{i_{m}} y_{O^{2-}} y_{V a} L_{i_{m}: O^{2-}, V a}^{L}
$$

where $i_{m}$ and $i_{n}$ represent the constituents in the first sublattice. In the above expressions, colons were used to separate species on different sublattices and commas to separate species on the same sublattice. No ternary or quaternary parameters were optimized for the liquid phase due to lack of experimental data, so the calculated liquidus for $\mathrm{Sr}-\mathrm{Co}-\mathrm{O}$ and $\mathrm{Sr}-\mathrm{Co}-\mathrm{Fe}-\mathrm{O}$ should be treated with caution.

\section{2. $\mathrm{Sr}_{2} \mathrm{Co}_{2} \mathrm{O}_{5}$ and $\mathrm{Sr}_{6} \mathrm{Co}_{5} \mathrm{O}_{15}$}

This research treated $\mathrm{Sr}_{2} \mathrm{Co}_{2} \mathrm{O}_{5}$ and $\mathrm{Sr}_{6} \mathrm{Co}_{5} \mathrm{O}_{15}$ as stoichiometric compounds. Their Gibbs energy functions were derived from the first-principle calculation results of Saal et al. [25, 30], with the enthalpy and entropy terms further optimized using phase diagram data.

\section{3. $\mathrm{Sr}_{3} \mathrm{Co}_{2} \mathrm{O}_{7}$}

$\mathrm{Sr}_{3} \mathrm{Co}_{2} \mathrm{O}_{7}$ was modeled with a 5-sublattice model reflecting its actual crystal structure. The model reads as follows:

$\left(\mathrm{Sr}^{2+}\right)_{1}\left(\mathrm{Sr}^{2+}\right)_{2}\left(\mathrm{Co}^{3+}\right)_{2}\left(\mathrm{O}^{2-}, \mathrm{Va}\right)_{6}\left(\mathrm{O}^{2-}\right)_{1}$

where Va represents vacancy (in this case oxygen ion vacancy). According to the Compound energy model (for modeling solid phases), vacancies with zero net charge are introduced on either the cation or oxygen ion sublattice or both according to the actual crystal structure information (i.e. sublattice occupation). The Gibbs energy for the end member $\left(\mathrm{Sr}^{2+}\right)_{1}\left(\mathrm{Sr}^{2+}\right)_{2}\left(\mathrm{Co}^{3+}\right)_{2}\left(\mathrm{O}^{2-}\right)_{6}\left(\mathrm{O}^{2-}\right)_{1}$ is formulated as

${ }^{o} G_{S r^{2+}: \mathrm{Sr}^{2+}: \mathrm{Co}^{3+}: \mathrm{O}^{2-}: \mathrm{O}^{2-}}^{\mathrm{S}_{\mathrm{C}} \mathrm{O}_{2} \mathrm{O}_{7}}=3^{o} \mathrm{G}^{\mathrm{SrO}}+2^{o} \mathrm{G}^{\mathrm{CoO}}+{ }^{o} G^{\mathrm{O}_{2}}+A_{0}+B_{0} * T$

and for the other one $\left(\mathrm{Sr}^{2+}\right)_{1}\left(\mathrm{Sr}^{2+}\right)_{2}\left(\mathrm{Co}^{3+}\right)_{2}(\mathrm{Va})_{6}\left(\mathrm{O}^{2-}\right)_{1}$ as

$$
{ }^{o} G_{S r^{2+}: S^{2+}: \mathrm{Co}^{3+}: \mathrm{Va}: \mathrm{O}^{2-}}^{\mathrm{Sr}_{2} \mathrm{O}^{2}}=3^{o} \mathrm{G}^{\mathrm{SrO}}+2^{\circ} \mathrm{G}^{\mathrm{CoO}}-2^{\circ} \mathrm{G}^{\mathrm{O}_{2}}
$$

where ${ }^{\circ} G^{\mathrm{SrO}},{ }^{o} G^{\mathrm{CoO}}$ and ${ }^{\circ} G^{O_{2}}$ were taken from Risold et al. [9], Chen et al. [10] and Dinsdale [56], respectively, and $A_{0}, B_{0}$ values were optimized using phase diagram data.

\subsection{Perovskite $\mathrm{SrCo}_{1-x} \mathrm{Fe}_{x} \mathrm{O}_{3-\delta}$}


A three-sublattice model was used for the perovskite phase, with the first sublattice (A site) for Sr cation $\left(\mathrm{Sr}^{2+}\right)$ and vacancy, the second (B site) for $\mathrm{Co}$ and $\mathrm{Fe}$ cations $\left(\mathrm{Co}^{2+}, \mathrm{Co}^{3+}, \mathrm{Co}^{4+}, \mathrm{Fe}^{2+}, \mathrm{Fe}^{3+}\right.$ and $\left.\mathrm{Fe}^{4+}\right)$ and vacancy, and the third (O site) for oxide ion and oxygen vacancy. Just as in the Sr-Fe-O system [8], cation and oxygen vacancies $(\mathrm{Va})$ were introduced to the $\mathrm{A} / \mathrm{B}$ and $\mathrm{O}$ site, respectively, in order to model oxygen non-stoichiometry and to maintain charge neutrality. The model reads as follows:

$\left(\mathrm{Sr}^{2+}, \mathrm{Va}\right)_{1}\left(\mathrm{Co}^{2+}, \mathrm{Co}^{3+}, \mathrm{Co}^{4+}, \mathrm{Fe}^{2+}, \mathrm{Fe}^{3+}, \mathrm{Fe}^{4+}, \mathrm{Va}\right)_{1}\left(\mathrm{O}^{2-}, \mathrm{Va}\right)_{3}$

The Gibbs energy of the perovskite phase is given by the following expression:

$G_{m}^{\text {perovskite }}=\sum_{i} \sum_{j} \sum_{k} y_{i} y_{j} y_{k}{ }^{o} G_{i: j: k}^{\text {perovskite }}+R T \sum_{i} y_{i} \ln y_{i}+R T \sum_{j} y_{j} \ln y_{j}+3 R T \sum_{k} y_{k} \ln y_{k}+{ }^{E} G_{m}^{\text {perovskite }}$

where $i, j, k$ represent the constituents in the first, second and third sublattices, respectively.

According to the current model, 28 end-members ( ${ }^{\circ} G_{i: j: k}^{\text {perovskite }}$ terms) need to be assigned a Gibbs energy value. In order to be consistent with the perovskite model used in Sr-Fe-O [8] and La-Co-O [59], the same Gibbs energy terms must be applied to all the common end-members. The thermodynamic descriptions of 16 common end-members were taken from Sr-Fe-O [8] while the other six were taken from La-Co-O [59]. The remaining six end-members belong to the $\mathrm{Sr}-\mathrm{Co}-\mathrm{O}$ system and were determined during this research. The strategy to obtain the Gibbs energy terms for these six end-members was to choose appropriate neutral end-members or their combinations as model parameters, which could be optimized using experimental data. As in the previous modeling of the perovskite phase [8, 60-62], a number of the most important end-members or their combinations were chosen as model parameters and these are listed below:

Stoichiometric $\mathrm{SrCoO}_{3}\left(\mathrm{Sr}^{2+}\right)_{1}\left(\mathrm{Co}^{4+}\right)_{1}\left(\mathrm{O}^{2-}\right)_{3}$. Its Gibbs energy function is given by:

${ }^{o} G_{S r^{2+}: \mathrm{Co}^{4+}: \mathrm{O}^{2-}}^{\text {perovkite }}={ }^{o} G^{S r O}+{ }^{o} G^{\mathrm{CoO}}+0.5^{o} G^{O_{2}}+A_{1}+B_{1} * T$

where $A_{1}, B_{1}$ are parameters optimized to reproduce thermodynamic and phase diagram data.

Reduced $\mathrm{SrCoO}_{3-\delta}\left(\mathrm{Sr}^{2+}\right)_{1}\left(\mathrm{Co}^{3+}\right)_{1}\left(\mathrm{O}^{2-}{ }_{5 / 6}, \mathrm{Va}_{1 / 6}\right)_{3}$. Its Gibbs energy function is given by:

$G_{m}=\frac{5}{6}{ }^{o} G_{S r^{2}: C O^{3+}: O^{-2}}^{\text {peroskite }}+\frac{1}{6}{ }^{o} G_{S r^{2}: C O^{3+}: V a}^{\text {peroskite }}+3 R T\left(\frac{5}{6} \ln \frac{5}{6}+\frac{1}{6} \ln \frac{1}{6}\right)={ }^{o} G^{S r O}+{ }^{o} G^{C o O}+0.25^{o} G^{O_{2}}+A_{2}+B_{2} * T$

and further reduced $\mathrm{SrCoO}_{3-\delta}\left(\mathrm{Sr}^{2+}\right)_{1}\left(\mathrm{Co}^{2+}\right)_{1}\left(\mathrm{O}^{2-}{ }_{2 / 3}, \mathrm{Va}_{1 / 3}\right)_{3}$

$G_{m}=\frac{2}{3}{ }^{o} G_{S r^{2+}: C o^{2+}: O^{2-}}^{\text {perovkite }}+\frac{1}{3}{ }^{o} G_{S r^{2+}: C o^{2+}: V a}^{\text {perovkite }}+R T\left(\frac{2}{3} \ln \frac{2}{3}+\frac{1}{3} \ln \frac{1}{3}\right)={ }^{o} G^{S r O}+{ }^{o} G^{C o O}+A_{3}+B_{3} * T$

where $A_{2}, B_{2}, A_{3}$ and $B_{3}$ are parameters to be optimized.

All the other end-members were correlated by the following reciprocal relations:

${ }^{o} G_{S r^{2+}: \mathrm{Co}^{4+}: \mathrm{O}^{2-}}^{\text {perovkite }}+{ }^{o} G_{\mathrm{Va}: \mathrm{Co}^{3+}: \mathrm{Va}}^{\text {perve }}-{ }^{o} G_{\mathrm{Sr}^{2+}: \mathrm{Co}^{4+}: \mathrm{Va}}^{\text {perovkite }}-{ }^{o} G_{\mathrm{Va}: \mathrm{Co}^{3+}: \mathrm{O}^{2-}}^{\text {pervoskite }}=\Delta G_{1}$ 


$$
\begin{aligned}
& { }^{o} G_{S r^{2+}: \mathrm{Co}^{4+}: \mathrm{O}^{2-}}^{\text {perovskit }}+{ }^{o} G_{\mathrm{Sr}^{2+}: \mathrm{Co}^{3+}: \mathrm{Va}}^{\text {perovskite }}-{ }^{o} G_{\mathrm{Sr}^{2+}: \mathrm{Co}^{4+}: \mathrm{Va}}^{\text {perovskite }}-{ }^{o} G_{\mathrm{Sr}^{2+}: \mathrm{Co}^{3+}: \mathrm{O}^{2-}}^{\text {perovkite }}=\Delta G_{2} \\
& { }^{o} G_{S r^{2+}: \mathrm{Co}^{4+}: \mathrm{O}^{2-}}^{\text {peroskit }}+{ }^{o} G_{\mathrm{Sr}^{2+}: \mathrm{Co}^{2+}: \mathrm{Va}}^{\text {peroskite }}-{ }^{o} G_{\mathrm{Sr}^{2+}: \mathrm{Co}^{4+}: \mathrm{Va}}^{\text {peroskite }}-{ }^{o} G_{\mathrm{Sr}^{2+}: \mathrm{Co}^{2+}: \mathrm{O}^{2-}}^{\text {peroskite }}=\Delta G_{3}
\end{aligned}
$$

Where $\Delta G_{x}(x=1,2,3)$ is the energy of the above the reciprocal reactions (Eqs. 11-13) and is called reciprocal energy. It determines the morphology of Gibbs energy surface of the phase, with a flat surface when $\Delta G=0$ and a curved one when $\Delta G>0$ (indicating a tendency for demixing). Further detail on reciprocal terms can be found in Hillert [55] and Povoden-Karadeniz et al. [63]. In this research, the reciprocal energy $\Delta G_{x}=0(x=1$, 2, 3) was chosen, following the same treatment by Povoden-Karadeniz [63], as no tendency of demixing was reported for the nonstoichiometric oxide solid solutions that were treated in this study. The Gibbs energy functions for the 6 end-members can be derived by solving Equations 8 to 13 .

The excess Gibbs energy ${ }^{E} G_{m}^{\text {perovskite }}$ is formulated as:

${ }^{E} G_{m}^{\text {perovskite }}=\sum_{i_{l}} \sum_{i_{k} \neq i_{l}} \sum_{j_{m}} y_{i_{k}} y_{i_{l}} y_{j_{m}} L_{i_{k}, i_{l}: j_{m}: O^{2-}}^{\text {perovkite }}+\sum_{i_{l}} \sum_{j_{m}} \sum_{j_{n} \neq j_{m}} y_{i_{l}} y_{j_{m}} y_{j_{n}} L_{i_{l}: j_{m}, j_{n}: O^{2-}}^{\text {perovkite }}$

where $i_{k}, i_{l}$ represent the constituents in the first sublattice (A site), and $j_{m}, j_{n}$ represent the constituents in the second sublattice (B site).

\section{5. $\mathrm{Sr}_{3} \mathrm{Fe}_{2-x} \mathrm{Co}_{x} \mathrm{O}_{7-\delta}$ and $\mathrm{Sr}_{4} \mathrm{Fe}_{6-x} \mathrm{Co}_{x} \mathrm{O}_{13-\delta}$}

To model the Co solubility in these two phases, Co cation was introduced to the Fe site. As the average Co valence state reported is around +3 , only $\mathrm{Co}^{3+}$ was included to keep the model simple. The Gibbs energy functions for $\mathrm{Sr}_{3} \mathrm{Fe}_{2-x} \mathrm{Co}_{x} \mathrm{O}_{7-\delta}$ and $\mathrm{Sr}_{4} \mathrm{Fe}_{6-x} \mathrm{Co}_{x} \mathrm{O}_{13-\delta}$ can be found in Table 2.

\subsection{Other ternary oxides phases}

Two more ternary oxides in $\mathrm{Sr}-\mathrm{Co}-\mathrm{O}$ were included in the present work: $\mathrm{Sr}_{4} \mathrm{Co}_{3} \mathrm{O}_{9}$ and $\mathrm{Sr}_{5} \mathrm{Co}_{4} \mathrm{O}_{12}$ were modeled as stoichiometric compounds. In $\mathrm{Sr}-\mathrm{Fe}-\mathrm{O}$, the description for $\mathrm{Sr}_{4} \mathrm{Fe}_{3} \mathrm{O}_{10}$ and $\mathrm{SrFe}_{12} \mathrm{O}_{19}$ was taken from $\mathrm{Sr}-\mathrm{Fe}-\mathrm{O}[11]$ without modification, as no Co solubility in these two compounds was reported in the literature.

Table 2 Parameters obtained for the ternary oxide phases in the Sr-Co-O system and the quaternary solid

\begin{tabular}{|c|c|}
\hline Phase & Parameters \\
\hline \multirow[t]{6}{*}{ Perovskite $^{b}$} & $\left(\mathrm{Sr}^{2+}, \mathrm{Va}\right)_{1}\left(\mathrm{Co}^{2+}, \mathrm{Co}^{3+}, \mathrm{Co}^{4+}, \mathrm{Fe}^{2+}, \mathrm{Fe}^{3+}, \mathrm{Fe}^{4+}, \mathrm{Va}\right)_{1}\left(\mathrm{O}^{2-}, \mathrm{Va}\right)_{3}$ \\
\hline & ${ }^{o} G_{S r^{+1}: \mathrm{Co}^{2+}: \mathrm{O}^{2-}}^{\text {perovkkite }}-H_{S r}^{S E R}-H_{C o}^{S E R}-3 H_{O}^{S E R}=+G S 2 O V+G H S E R O O+15.8759 T$ \\
\hline & ${ }^{o} G_{S r^{2+}: \mathrm{Co}^{3+}: \mathrm{O}^{2-}}^{\text {perosite }}-H_{S r}^{S E R}-H_{C o}^{S E R}-3 H_{O}^{S E R}=+0.5 G H S E R O O+G S 3 O V+11.2379 T$ \\
\hline & ${ }^{o} G_{S r^{2+}: \mathrm{Co}^{4+}: O^{2-}}^{\text {peroskite }}-H_{S r}^{S E R}-H_{C o}^{S E R}-3 H_{O}^{S E R}=+G S 4 O$ \\
\hline & ${ }^{o} G_{S r^{2+}: \mathrm{Co}^{2+}: \mathrm{Va}}^{\text {peroske }}-H_{S r}^{S E R}-H_{\mathrm{Co}}^{S E R}=+G S 2 \mathrm{OV}-2 \mathrm{GHSEROO}+15.8759 \mathrm{~T}$ \\
\hline & ${ }^{o} G_{S r^{2+}: \mathrm{Co}^{3+}: \mathrm{Va}}^{\text {perosite }}-H_{S r}^{S E R}-H_{\mathrm{Co}}^{S E R}=+G S 3 \mathrm{OV}-2.5 \mathrm{GHSEROO}+11.2379 \mathrm{~T}$ \\
\hline
\end{tabular}
solution phases in the $\mathrm{Sr}-\mathrm{Co}-\mathrm{Fe}-\mathrm{O}$ system $^{\text {a }}$ 


\begin{tabular}{|c|c|}
\hline & 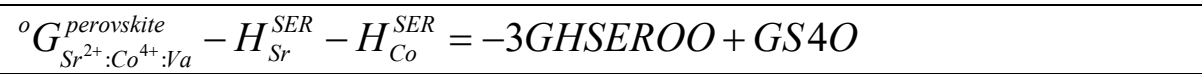 \\
\hline & 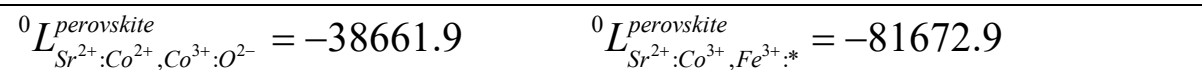 \\
\hline & 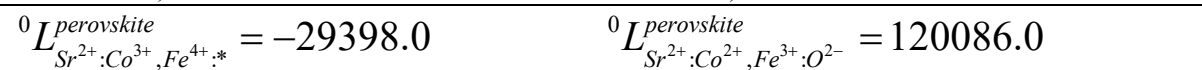 \\
\hline \multirow[t]{2}{*}{$\mathrm{Sr}_{2} \mathrm{Co}_{2} \mathrm{O}_{5}$} & $\left(\mathrm{Sr}^{2+}\right)_{2}\left(\mathrm{Co}^{2+}\right)_{1}\left(\mathrm{Co}^{4+}\right)_{1}\left(\mathrm{O}^{2-}\right)_{5}$ \\
\hline & 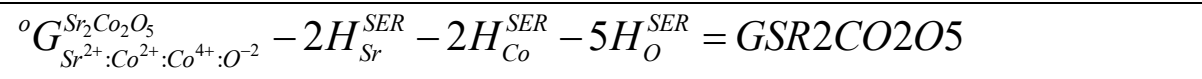 \\
\hline \multirow[t]{3}{*}{$\mathrm{Sr}_{3} \mathrm{Co}_{2} \mathrm{O}_{7}$} & $\left(\mathrm{Sr}^{2+}\right)_{1}\left(\mathrm{Sr}^{2+}\right)_{2}\left(\mathrm{Co}^{3+}\right)_{2}\left(\mathrm{O}^{2-}, \mathrm{Va}\right)_{6}\left(\mathrm{O}^{2-}\right)_{1}$ \\
\hline & $\begin{array}{l}{ }^{o} G_{S_{r} r^{2}: S r_{2}{ }^{2+}: C^{3+}: O^{2-}: O^{2-}}-3 H_{S r}^{S E R}-2 H_{C o}^{S E R}-7 H_{O}^{S E R}=3 G S R O S O L+2 G C O O S \\
+2 G H S E R O O-100000+60 T\end{array}$ \\
\hline & 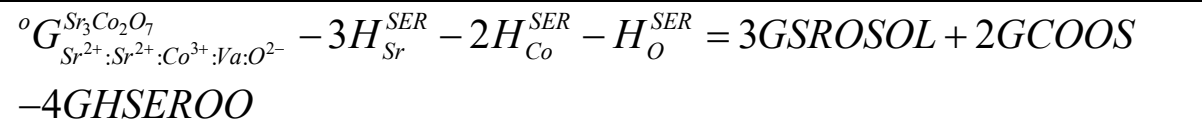 \\
\hline \multirow[t]{4}{*}{$\mathrm{Sr}_{3} \mathrm{Fe}_{2-x} \mathrm{Co}_{x} \mathrm{O}_{7-\delta}{ }^{\mathrm{b}}$} & $\left(\mathrm{Sr}^{2+}\right)_{1}\left(\mathrm{Sr}^{2+}\right)_{2}\left(\mathrm{Co}^{3+}, \mathrm{Fe}^{3+}, \mathrm{Fe}^{4+}\right)_{2}\left(\mathrm{O}^{2-}, \mathrm{Va}\right)_{6}\left(\mathrm{O}^{2-}\right)_{1}$ \\
\hline & 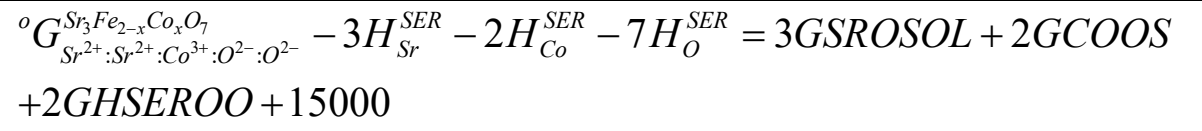 \\
\hline & 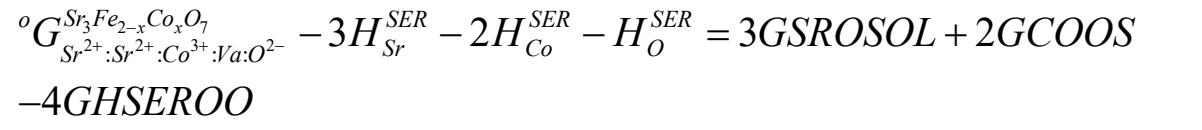 \\
\hline & 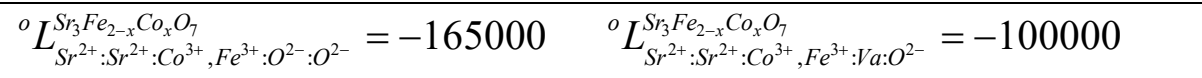 \\
\hline \multirow[t]{3}{*}{$\mathrm{Sr}_{4} \mathrm{Fe}_{6-x} \mathrm{Co}_{x} \mathrm{O}_{13}{ }^{\mathrm{b}}$} & $\left(\mathrm{Sr}^{2+}\right)_{4}\left(\mathrm{Fe}^{3+}\right)_{4}\left(\mathrm{Co}^{3+}, \mathrm{Fe}^{2+}, \mathrm{Fe}^{3+}, \mathrm{Fe}^{4+}\right)_{2}\left(\mathrm{O}^{2-}\right)_{12}\left(\mathrm{O}^{2-}, \mathrm{Va}\right)_{2}$ \\
\hline & 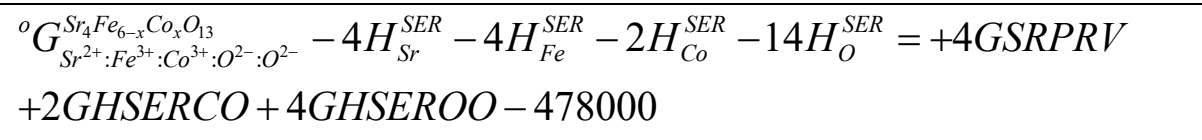 \\
\hline & 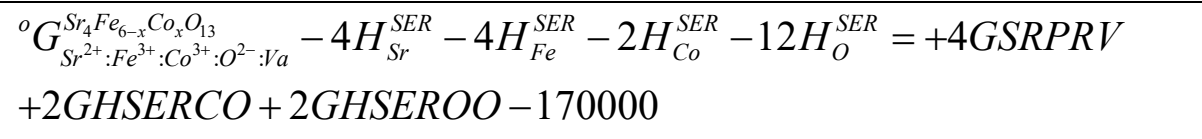 \\
\hline \multirow[t]{6}{*}{$\mathrm{Sr}_{6} \mathrm{Co}_{5} \mathrm{O}_{15}$} & $\left(\mathrm{Sr}^{2+}\right)_{6}\left(\mathrm{Co}^{4+}\right)_{4}\left(\mathrm{Co}^{2+}\right)_{1}\left(\mathrm{O}^{2-}\right)_{15}$ \\
\hline & 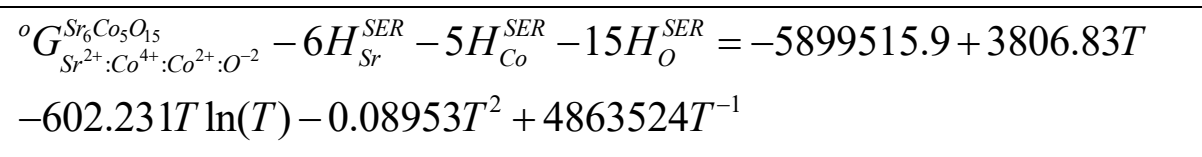 \\
\hline & Functions \\
\hline & $G S 2 O V=G S R O S O L+G C O O S+28889.74-15.20777 T$ \\
\hline & GS3OV $=$ GSROSOL + GCOOS + 0.5GHSEROO $-20754.002+10.9971$ \\
\hline & $G S 4 O=G S R O S O L+G C O O S+G H S E R O O-86550.2+75.64357 T$ \\
\hline
\end{tabular}




\begin{tabular}{|l|l|}
\hline & GCOOS $=-252530+270.075 T-47.825 T \ln (T)-0.005112 T^{2}+225008 T^{-1}$ \\
\hline & GSROSOL $=-607870+268.9 T-47.56 T \ln (T)-0.00307 T^{2}+190000 T^{-1}$ \\
\hline & GSR2CO2O5=-1864898.9+1216.424-213.734T $\ln (T)-0.023799 T^{2}$ \\
& $+1635410.1 T^{-1}$ \\
\hline & GSR3FE2O7 $=2 G S R P R V+G S R O S O L$ \\
\hline & GSRPRV $=$ GSROSOL $+0.5 G F E 2 O 3-44701-8.73 T$ \\
\hline & GHSERCO $=+310.241+133.36601 T-25.0861 T \ln (T)$ \\
& $-0.002654739 T^{2}-1.7348 \times 10^{-7} T^{3}+72527 T^{-1}$ \\
& $298.15<T<1768$ \\
& $-17197.666+253.28374 T-40.5 T \ln (T)+9.3488 \times 10^{30} T^{-9}$ \\
& $1768<T<6000$ \\
\hline & $G H S E R O O=-3480.87226-25.5028601 T-11.1355068 T \ln (T)$ \\
& $-0.005098873 T^{2}+6.6184604 \times 10^{-7} T^{3}-38364.8742 T^{-1}$ \\
& $298.15<T<1000$ \\
& $-6568.76015+12.6600017 T-16.8138015 T \ln (T)$ \\
& $-5.9579637 \times 10^{-4} T^{2}+6.78055555 \times 10^{-9} T^{3}+262904.778 T^{-1}$ \\
& $1000<T<3300$ \\
& $-13986.728+31.259625 T-18.9536 T \ln (T)-4.25243 \times 10^{-4} T^{2}$ \\
& $+1.0721 \times 10^{-8} T^{3}+4383200 T^{-1}$ \\
& $3300<T<6000$ \\
\hline &
\end{tabular}

a All parameters are in SI units: J, mol, $\mathrm{K}$ and Pa.

${ }^{b}$ The Gibbs energy terms for the end-members belonging to Sr-Fe-O can be found in Reference [8].

\subsection{Optimization}

Table 2 lists a set of optimized thermodynamic parameters obtained in this research for the ternary oxide phases in Sr-Co-O and for the quaternary solid solution phases in Sr-Co-Fe-O. The evaluation of the model parameters was carried out using recurrent runs of the PARROT program [64] in the Thermo-Calc software, which works by minimizing the square sum of the differences between experimental values and computed ones. In the optimization, each piece of experimental information is given a certain weight by assessing the quality of experiments. The weights were adjusted during the assessment until most of the experimental data were accounted for within the uncertainty limits stated.

In this research, for the perovskite phase, $A_{1}$ in Eq. 8 was optimized with enthalpy of formation from CalleVallejo et al. [23], while $B_{1}$ was obtained by assuming that the entropy of $\mathrm{SrCoO}_{3-\delta}$ at $298 \mathrm{~K}$ is similar to that of $\mathrm{Sr}_{2} \mathrm{Co}_{2} \mathrm{O}_{5}$, and making further adjustments using phase diagram data. $A_{2}$ and $B_{2}$ in Eq.9, $A_{3}$ and $B_{3}$ in Eq. 10, and 
one interaction parameter ${ }^{0} L_{S^{2+}: \mathrm{Co}^{2+}, \mathrm{Co}^{3+}: \mathrm{O}^{2-}}^{\text {pervate }}$ were optimized using phase diagram data and oxygen nonstoichiometry data.

As mentioned in Section 3.3, parameters for $\mathrm{Sr}_{2} \mathrm{Co}_{2} \mathrm{O}_{5}$ and $\mathrm{Sr}_{6} \mathrm{Co}_{5} \mathrm{O}_{15}$ were further adjusted using phase diagram data from Takeda et al. and Vashook et al. [13, 16], and, with lower weight in the optimization, enthalpies of formation from first-principles analysis [23]. While tremendous progress on accuracy of firstprinciple results has been achieved for metallic phases, the same quality does not apply to complex oxide phases due to many free parameters associated with competition between various interactions on the atomistic level. Thus, we expect higher uncertainty of first principle calculations compared to experiments. Nonetheless, deviation of assessed thermodynamic data from first principles results [23] was minimal. $\mathrm{For} \mathrm{Sr}_{3} \mathrm{Co}_{2} \mathrm{O}_{7}, A_{0}$ and $B_{0}$ in Eq. 5 were adjusted such as to make the phase stable at $1373 \mathrm{~K}$ in air in accordance with the findings from Aksenova et al. and Cherepanov et al. [34, 65].

For the Sr-Co-Fe-O system, three interaction parameters ${ }^{0} L_{S r^{2+}: \mathrm{CO}^{3+}, \mathrm{Fe}^{3+}: *}^{\text {perovkit }},{ }^{0} \mathrm{~L}_{\mathrm{Sr}^{2+}: \mathrm{Co}^{3+}, \mathrm{Fe}^{4+}: *}^{\text {perovkite }},{ }^{0} \mathrm{~L}_{\mathrm{Sr}^{2+}: \mathrm{Co}^{2+}, \mathrm{Fe}^{3+}: *}^{\text {pervskite }}$ for the perovskite phase were optimized using phase diagram and oxygen non-stoichiometry data. In addition,

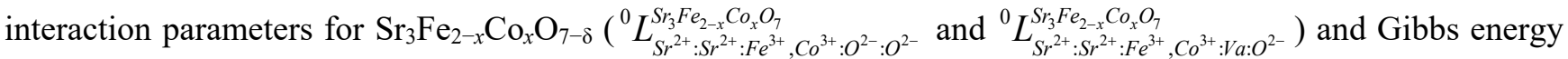

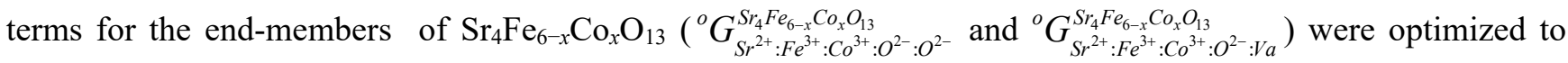
account for the Co solubility in $\mathrm{Sr}_{3} \mathrm{Fe}_{2} \mathrm{O}_{7}$ and $\mathrm{Sr}_{4} \mathrm{Fe}_{6} \mathrm{O}_{13}$, respectively. The selection of interaction parameters was based on availability of experimental data. The parameters having direct control or the largest influence on the experimental data were selected for optimization. In general, over-optimization should be prevented, i.e. use as less interaction parameters as possible.

\section{Results and discussion}

\subsection{The Sr-Co-O system}

The enthalpy of formation, entropy, and Gibbs energy of formation calculated in this research for $\mathrm{Sr}_{6} \mathrm{Co}_{5} \mathrm{O}_{15}$, $\mathrm{Sr}_{2} \mathrm{Co}_{2} \mathrm{O}_{5}$ and $\mathrm{SrCoO}_{3-\delta}$ at $298 \mathrm{~K}$ are listed in Table 3, together with the values from the literature. The CALPHAD results deviate in general from those obtained via first principle calculations. For further refinement of the Gibbs energy functions, complementary thermodynamic measurements would be advantageous.

Table 3 Enthalpy of formation, entropy, and Gibbs energy of formation for $\mathrm{Sr}_{6} \mathrm{Co}_{5} \mathrm{O}_{15}, \mathrm{Sr}_{2} \mathrm{Co}_{2} \mathrm{O}_{5}$ and $\mathrm{SrCoO}_{3-\delta}$ at $298 \mathrm{~K}$

\begin{tabular}{llll}
\hline Phase & Results & Method & Reference \\
\hline $\mathrm{Sr}_{6} \mathrm{Co}_{5} \mathrm{O}_{15}$ & $\Delta^{o} H_{f, \text { elements }}^{S_{r_{6} \mathrm{CO}_{5} \mathrm{O}_{15}}}(298 K)=-206.899 \mathrm{~kJ} / \mathrm{mol}$ & First principle & {$[25,30]$} \\
& $\Delta^{o} H_{f, \text { elements }}^{S_{r_{6} C 0_{5} \mathrm{O}_{15}}}(298 K)=-206.899 \mathrm{~kJ} / \mathrm{mol}$ & CALPHAD & {$[25]$} \\
& $\Delta^{o} H_{f, \text { elements }}^{S_{6} \text { Co } \mathrm{O}_{5} \mathrm{O}_{5}}(298 K)=-218.437 \mathrm{~kJ} / \mathrm{mol}$ & CALPHAD & This work \\
\hline
\end{tabular}




\begin{tabular}{|c|c|c|c|}
\hline & ${ }^{o} S^{S_{6} 6 o_{5} O_{15}}(298 K)=17.348 \mathrm{~J} /(\mathrm{mol} \cdot \mathrm{K})$ & First principle & {$[25,30]$} \\
\hline & ${ }^{o} S^{S_{r_{6}} C O_{5} O_{15}}(298 K)=22.8 \mathrm{~J} /(\mathrm{mol} \cdot \mathrm{K})$ & CALPHAD & {$[25]$} \\
\hline & ${ }^{o} S^{S_{r_{6}} C_{0_{5} O_{15}}}(298 K)=12.87 \mathrm{~J} /(\mathrm{mol} \cdot \mathrm{K})$ & CALPHAD & This work \\
\hline \multirow[t]{6}{*}{$\mathrm{Sr}_{2} \mathrm{Co}_{2} \mathrm{O}_{5}$} & $\Delta^{o} H_{f, \text { elements }}^{S_{2} \mathrm{Co}_{2} O_{5}}(298 K)=-210.112 \mathrm{~kJ} / \mathrm{mol}$ & First principle & {$[25]$} \\
\hline & $\Delta^{o} H_{f, \text { elements }}^{S_{r_{2}} \mathrm{Co}_{2} \mathrm{O}_{5}}(298 \mathrm{~K})=-150.309 \mathrm{~kJ} / \mathrm{mol}$ & CALPHAD & {$[25]$} \\
\hline & $\Delta^{o} H_{f, \text { elements }}^{\mathrm{St}_{2} \mathrm{Co}_{2} \mathrm{O}_{5}}(298 \mathrm{~K})=-198.676 \mathrm{~kJ} / \mathrm{mol}$ & CALPHAD & This work \\
\hline & ${ }^{o} S^{\mathrm{Si}_{2} \mathrm{CO}_{2} \mathrm{O}_{5}}(298 \mathrm{~K})=18.25 \mathrm{~J} /(\mathrm{mol} \cdot \mathrm{K})$ & First principle & {$[25]$} \\
\hline & ${ }^{o} S^{\mathrm{Sl}_{2} \mathrm{Co}_{2} \mathrm{O}_{5}}(298 \mathrm{~K})=55.095 \mathrm{~J} /(\mathrm{mol} \cdot \mathrm{K})$ & CALPHAD & {$[25]$} \\
\hline & ${ }^{o} S^{\mathrm{Sr}_{2} \mathrm{Co}_{2} \mathrm{O}_{5}}(298 \mathrm{~K})=27.52 \mathrm{~J} /(\mathrm{mol} \cdot \mathrm{K})$ & CALPHAD & This work \\
\hline \multirow[t]{5}{*}{$\mathrm{SrCoO}_{3-\delta}$} & $\Delta^{o} G_{f, \text { elements }}^{\mathrm{SrCOO}_{3}}(298 \mathrm{~K})=-163 \mathrm{~kJ} / \mathrm{mol}$ & First principle & {$[23]$} \\
\hline & $\Delta^{o} G_{f, \text { elements }}^{\mathrm{SrCOO}_{3}}(298 \mathrm{~K})=-171 \mathrm{~kJ} / \mathrm{mol}$ & CALPHAD & {$[25]$} \\
\hline & $\Delta^{o} G_{f, \text { elements }}^{\mathrm{SrCOO}_{3}}(298 \mathrm{~K})=-183 \mathrm{~kJ} / \mathrm{mol}$ & CALPHAD & This work \\
\hline & ${ }^{o} S^{\mathrm{SrCoO}_{3}}(298 \mathrm{~K})=55.57 \mathrm{~J} /(\mathrm{mol} \cdot \mathrm{K})$ & CALPHAD & {$[25]$} \\
\hline & ${ }^{o} S^{\mathrm{SrCoO}_{3}}(298 \mathrm{~K})=27.26 \mathrm{~J} /(\mathrm{mol} \cdot \mathrm{K})$ & CALPHAD & This work \\
\hline
\end{tabular}

The calculated phase diagrams for $\mathrm{SrO}_{x}-\mathrm{CoO}_{y}$ from this work are shown in Figs. 1-3. Fig. 1 presents the calculated $\mathrm{SrO}_{x}-\mathrm{CoO}_{y}$ phase diagram in air. Phase relations are in particular delicate inside the composition range of $x(\mathrm{Co}) /(x(\mathrm{Co})+x(\mathrm{Sr}))=0.4-0.5$ and the temperature range of $T=1100-1500 \mathrm{~K}$. In this relatively small region, 5 two-phase equilibria are predicted by the modeling. In addition to $\mathrm{Sr}_{6} \mathrm{Co}_{5} \mathrm{O}_{15}$, Wong-Ng et al. [33] reported the existence of $\mathrm{Sr}_{4} \mathrm{Co}_{3} \mathrm{O}_{9}$ and $\mathrm{Sr}_{5} \mathrm{Co}_{4} \mathrm{O}_{12}$ at $1123 \mathrm{~K}$ in air. According to the current modeling, however, $\mathrm{Sr}_{4} \mathrm{Co}_{3} \mathrm{O}_{9}$ and $\mathrm{Sr}_{5} \mathrm{Co}_{4} \mathrm{O}_{12}$ phases cannot co-exist with $\mathrm{Sr}_{6} \mathrm{Co}_{5} \mathrm{O}_{15}$ at $1123 \mathrm{~K}$ in air. These two phases were therefore excluded in the final database. The calculated stable temperature range for $\mathrm{Sr}_{3} \mathrm{Co}_{2} \mathrm{O}_{7-\delta}$ in air is $1246-$ $1610 \mathrm{~K}$. Fig. 2 shows the calculated isothermal $P \mathrm{O}_{2}$-composition $\left(P \mathrm{O}_{2}=10^{-14}-1\right.$ bar $)$ phase diagrams at temperatures $1073-1373 \mathrm{~K}$. The stable phases at different conditions can be read directly from the figures. 


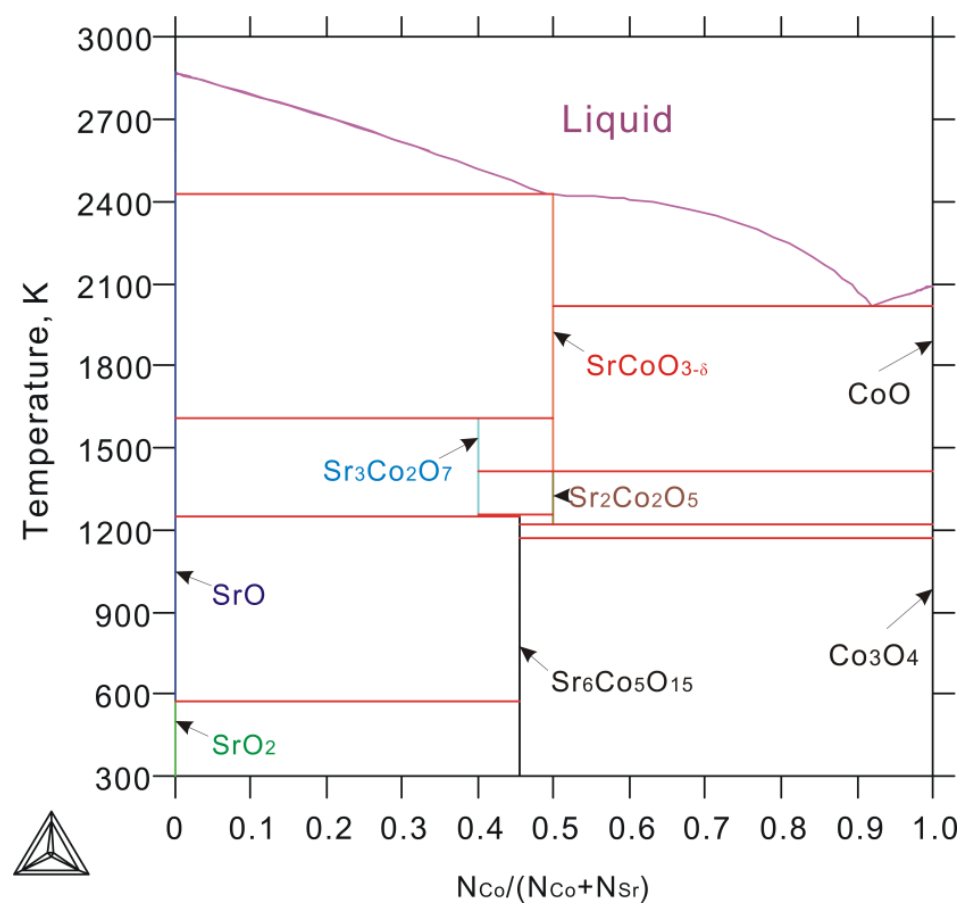

Fig. 1. Calculated phase diagram of $\mathrm{SrO}_{x}-\mathrm{CoO}_{y}$ in air based on the parameters obtained in this research.

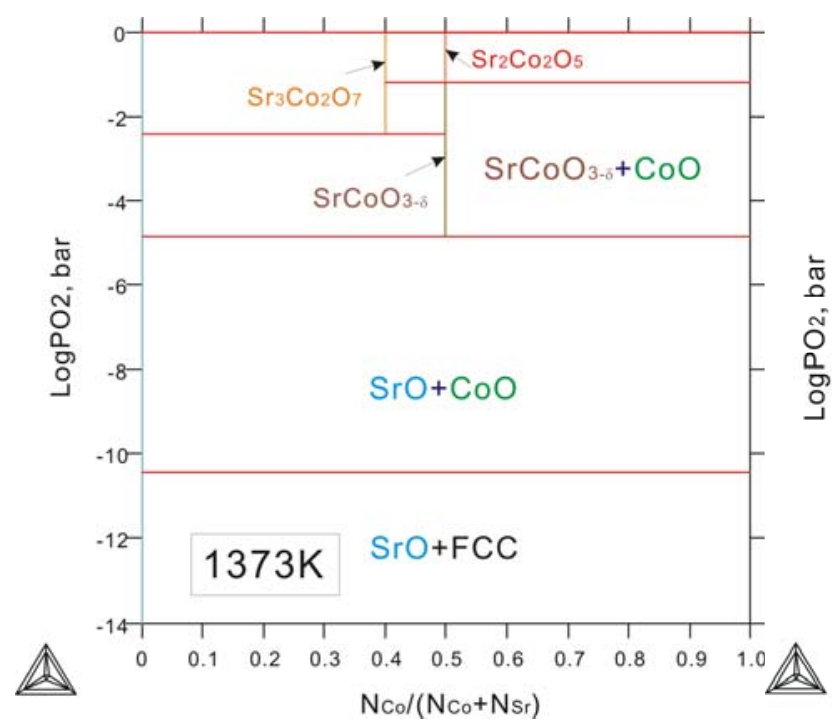

(a)

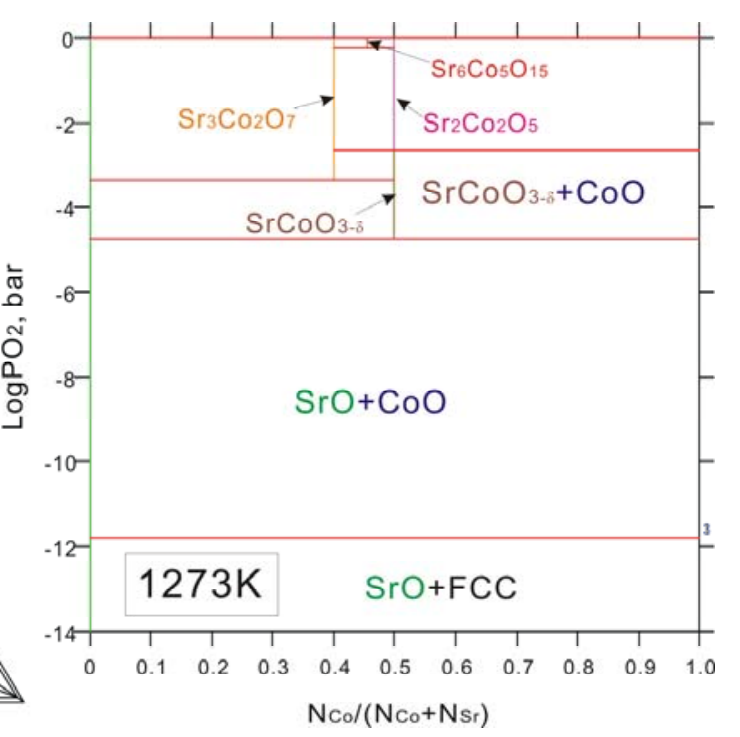

(b) 


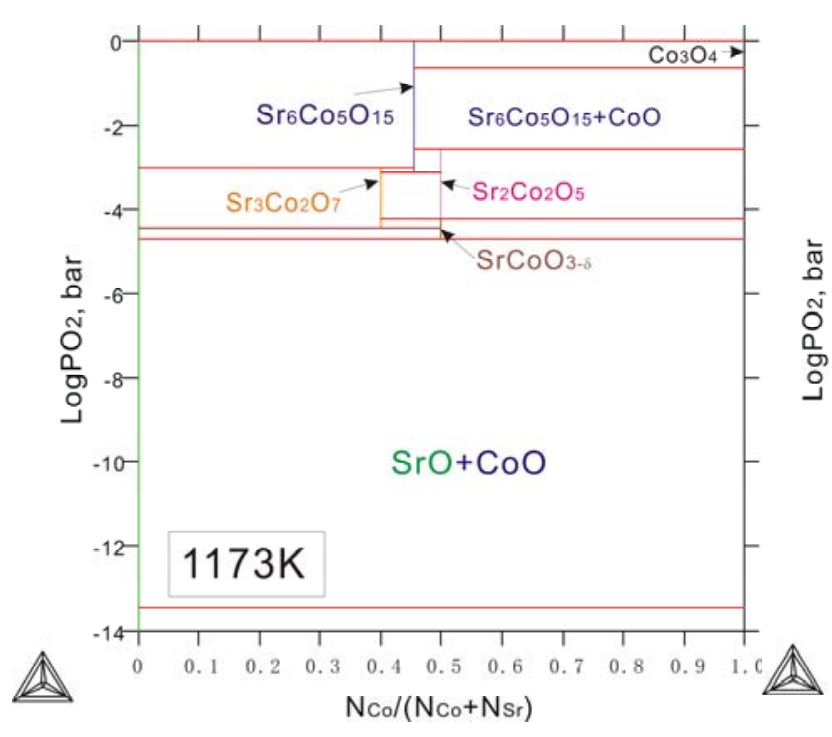

(c)

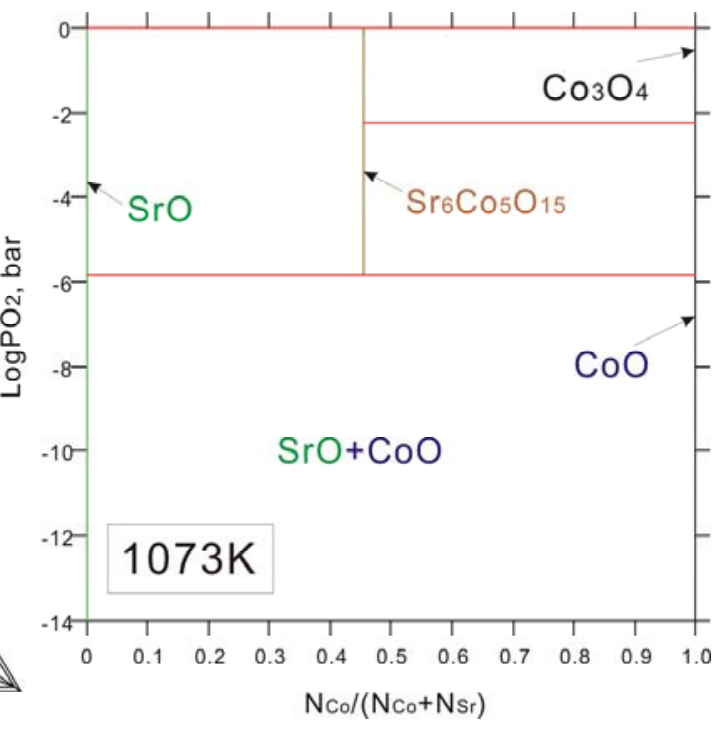

(d)

Fig. 2. Calculated isothermal $P \mathrm{O}_{2}$-composition phase diagrams at different temperatures based on the parameters obtained in this research. (a) $1373 \mathrm{~K}$, (b) $1273 \mathrm{~K}$, (c) $1173 \mathrm{~K}$, (d) $1073 \mathrm{~K}$. FCC is the metallic Co phase.

$\mathrm{SrCoO}_{3-\delta}$ is one of the most important oxides in $\mathrm{Sr}-\mathrm{Co}-\mathrm{O}$ and its stability depends strongly on temperature and oxygen partial pressure. Fig. 3 shows the calculated stability phase diagram for a composition of $x(\mathrm{Co}) /(x(\mathrm{Co})+x(\mathrm{Sr}))=0.5$ in comparison with experimental results. The single phase or two-phase region is labeled with phase names and the line between two neighboring regions represents a univariant reaction. As shown in Fig. 3, the deviation between the calculations and the experimental results is within a reasonable range. The $\mathrm{SrCoO}_{3-\delta}$ perovskite phase is stable only at high temperature. In a temperature range of $1250-1423 \mathrm{~K}$, $\mathrm{SrCoO}_{3-\delta}$ is stable at $\mathrm{PO}_{2}=10^{-0.5}-10^{-4.8}$ bar, and its stability decreases with decreasing temperature. The type of diagram shown in Fig. 3 can be used to explore the stability range (temperature and oxygen partial pressure) for required phases under a given composition. 


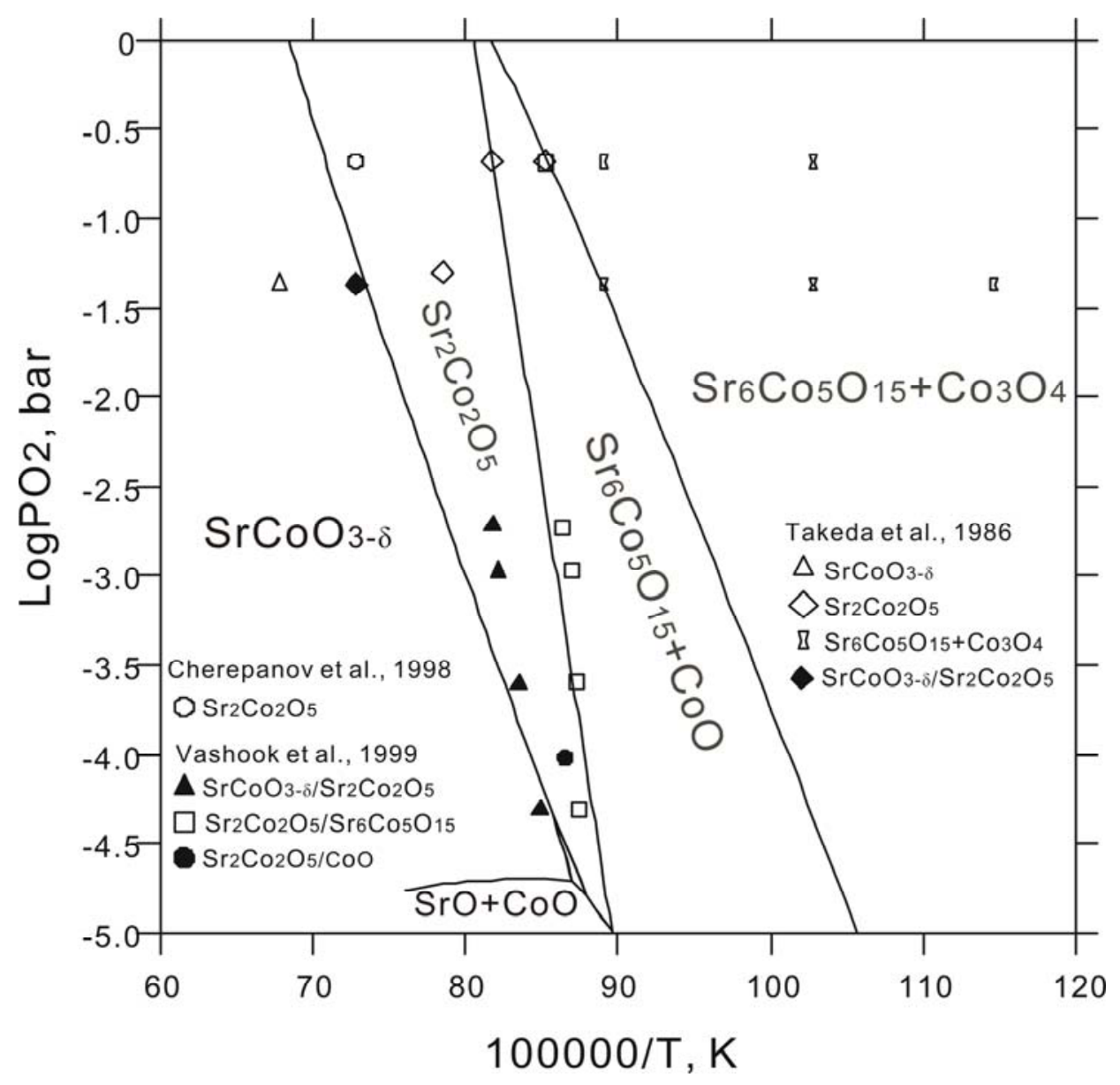

Fig. 3. Calculated stability diagram of Sr-Co-O based on the parameters obtained in this research for a composition of $x(\mathrm{Co}) /(x(\mathrm{Co})+x(\mathrm{Sr}))=0.5$ with experimental data from Cherepanov et al. [65], Vashook et al. [16] and Takeda et al. [13] included. The symbols represent single-phase or two-phase region or phase boundary between two neighboring regions, e.g. $\mathrm{Sr}_{2} \mathrm{Co}_{2} \mathrm{O}_{5} / \mathrm{Sr}_{6} \mathrm{Co}_{5} \mathrm{O}_{15}$.

Fig. 4 plots site fractions in $\mathrm{SrCoO}_{3-\delta}$ in air and at $\mathrm{PO}_{2}=1 \mathrm{~Pa}$ calculated in this research. At low temperatures where $\mathrm{SrCoO}_{3-\delta}$ is metastable, Co exists mainly as $\mathrm{Co}^{4+}$ in $\mathrm{SrCoO}_{3-\delta}$. At high temperatures, $\mathrm{SrCoO}_{3-\delta}$ has a large oxygen vacancy at the $\mathrm{O}$ site where $\mathrm{Co}^{3+}$ and $\mathrm{Co}^{2+}$ form. The results presented in Figure 4 should be treated with caution, as no validation is conducted due to lack of experimental data on ion distribution and charge disproportion in $\mathrm{SrCoO}_{3-\delta}$ at different temperatures and $\mathrm{PO}_{2}$. Fig. 5 shows the oxygen nonstoichiometry in $\mathrm{SrCoO}_{x}$ calculated in this research, which agrees very well with the experimental results. 


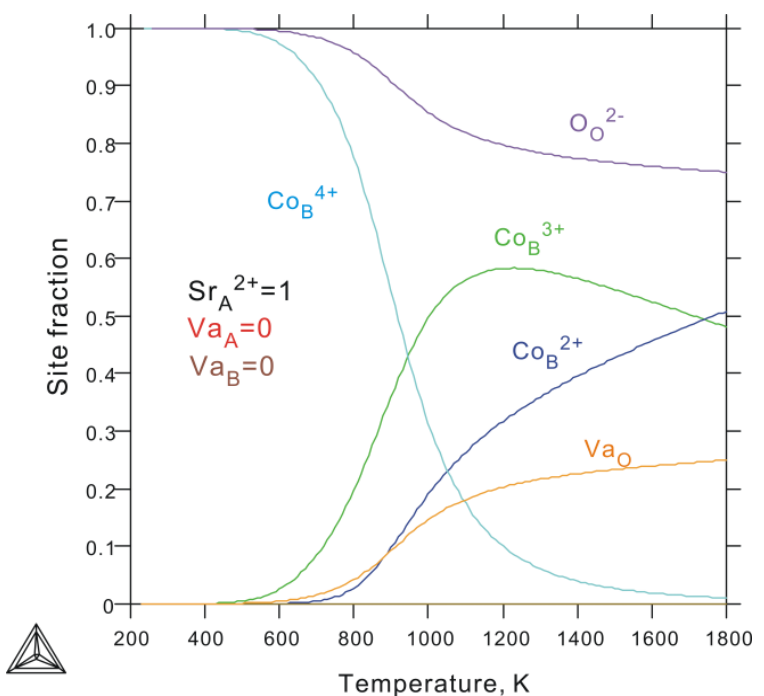

(a)

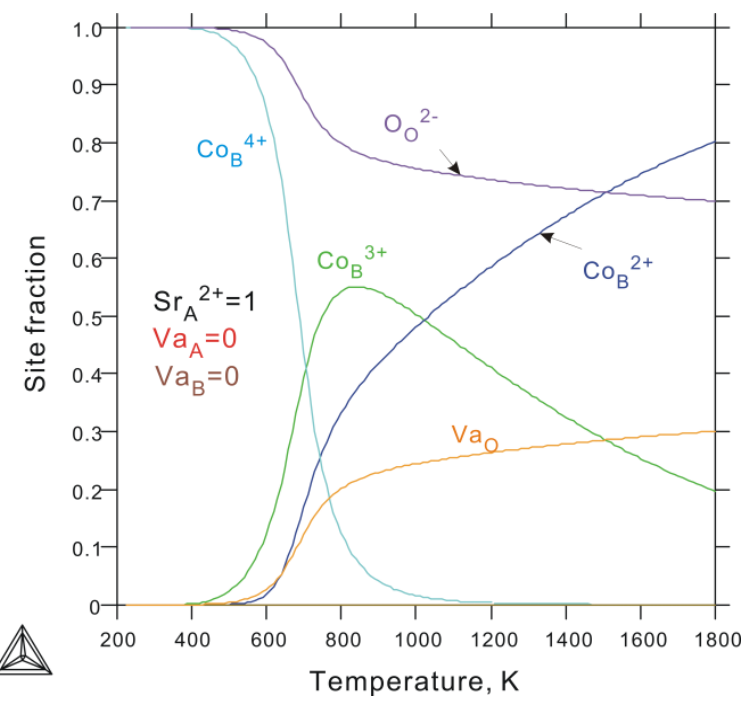

(b)

Fig. 4. Site fractions in $\mathrm{SrCoO}_{3-\delta}$. (a) in air (b) at $\mathrm{PO}_{2}=1 \mathrm{~Pa}$.

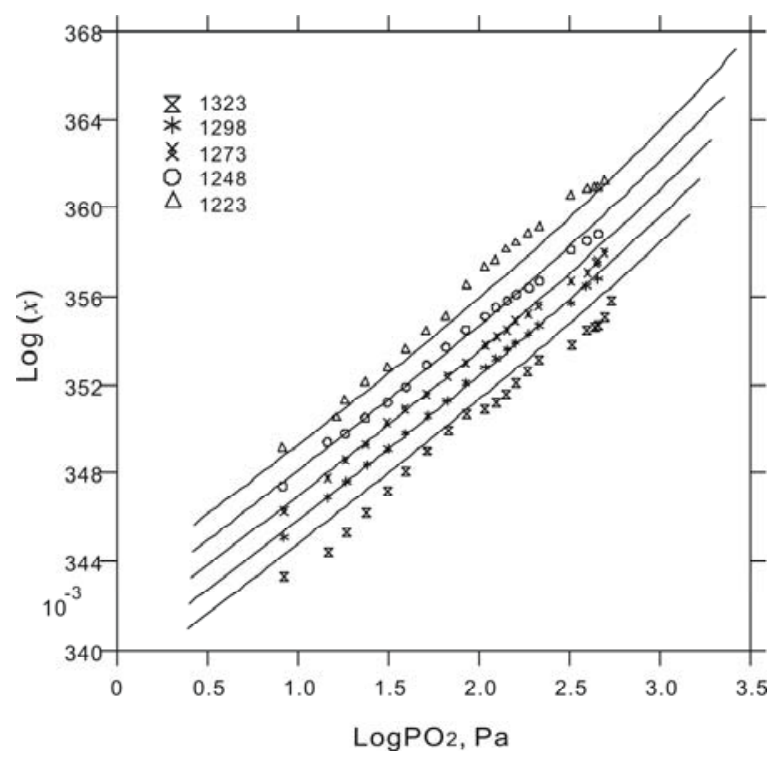

Fig. 5. Calculated oxygen nonstoichiometry $\left(x\right.$ in $\left.\mathrm{SrCoO}_{x}\right)$ as a function of $\log P \mathrm{O}_{2}$ in comparison with experimental data from Vashook et al. [17].

\subsection{The $\mathrm{Sr}-\mathrm{Co}-\mathrm{Fe}-\mathrm{O}$ system}

Fig. 6 presents the calculated $\mathrm{SrO}-\mathrm{Fe}_{2} \mathrm{O}_{3}-\mathrm{CoO}_{x}$ isothermal sections at $1373 \mathrm{~K}$ and $1173 \mathrm{~K}$ in air. The calculated isothermal section at $1373 \mathrm{~K}$ agree quite well with most of the experiment data from Aksenova et al. [34], except for the Co solubility in $\mathrm{Sr}_{3} \mathrm{Fe}_{2-y} \mathrm{Co}_{y} \mathrm{O}_{7-\delta}$. As presented in the isothermal section at $1173 \mathrm{~K}$ in Fig. 6b,

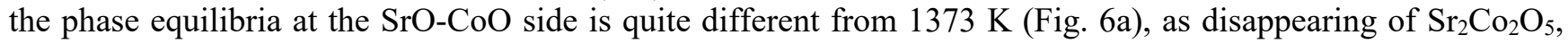
$\mathrm{Sr}_{3} \mathrm{Co}_{2} \mathrm{O}_{7}$, and forming $\mathrm{Sr}_{6} \mathrm{Co}_{5} \mathrm{O}_{15}$. At both temperatures, the $\mathrm{SrCo}_{1-x} \mathrm{Fe}_{x} \mathrm{O}_{3-\delta}$ perovskite phase is more stable on 
the $\mathrm{Fe}$-rich side (i.e. close to $\mathrm{SrFeO}_{3-\delta}$ ) and forms secondary phases on the Co-rich side. Experimental studies on phase equilibria in $\mathrm{SrO}-\mathrm{Fe}_{2} \mathrm{O}_{3}-\mathrm{CoO}_{x}$ at other temperatures under varying oxygen partial pressures would thus be valuable to validate the calculations and the database of Sr-Co-Fe-O. Fig. 7 plots the phase fraction for the composition $\mathrm{SrFe}_{1-x} \mathrm{Co}_{x} \mathrm{O}_{3}$ at $1273 \mathrm{~K}$ and $973 \mathrm{~K}$ in air. According to the calculation, the $\mathrm{SrFe}_{1-x} \mathrm{Co}_{x} \mathrm{O}_{3}$ perovskite is stable when $x<0.64$ at $1273 \mathrm{~K}$, and when $x<0.35$ at $973 \mathrm{~K}$. Table 4 lists the calculated Co solubility in $\mathrm{Sr}_{4} \mathrm{Fe}_{6-x} \mathrm{Co}_{x} \mathrm{O}_{13}$ at different temperatures in air, as compared with experimental results. It clearly shows that the Co solubility in $\mathrm{Sr}_{4} \mathrm{Fe}_{6-x} \mathrm{Co}_{x} \mathrm{O}_{13}$ decreases with decreasing temperature.

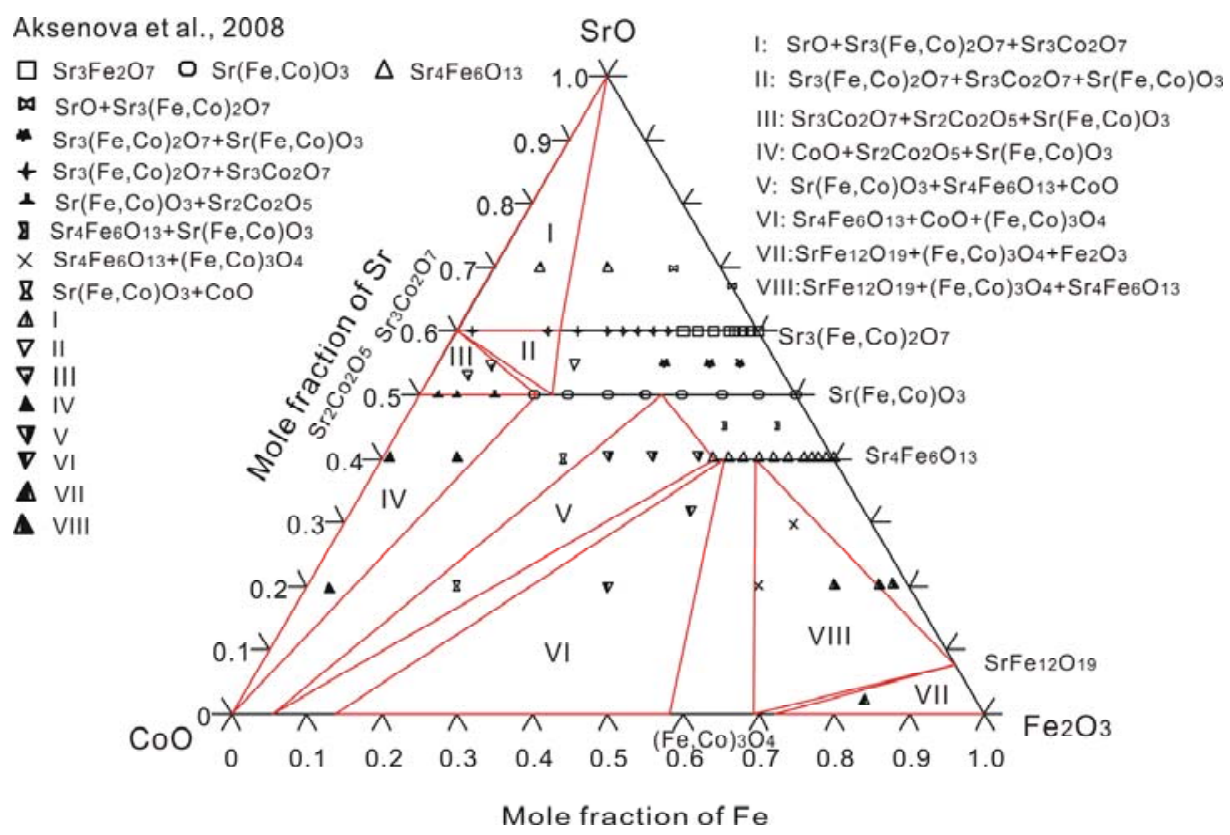

(a)

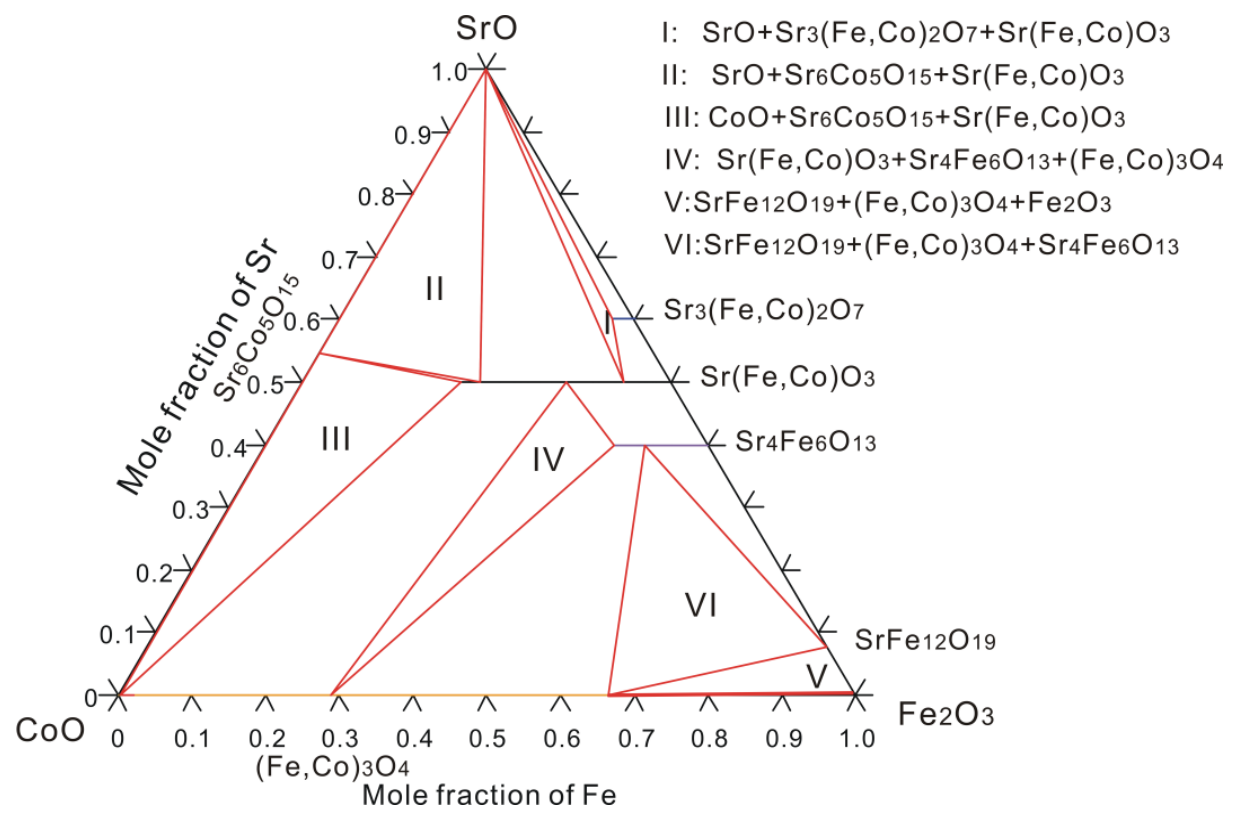

(b) 
Fig. 6. Calculated isotheromal sections of $\mathrm{SrO}-\mathrm{Fe}_{2} \mathrm{O}_{3}-\mathrm{CoO}_{x}$ in air compared with the experimental data from Aksenova $e t$ al. [34]. a) at $1373 \mathrm{~K}$, b) at $1173 \mathrm{~K}$.

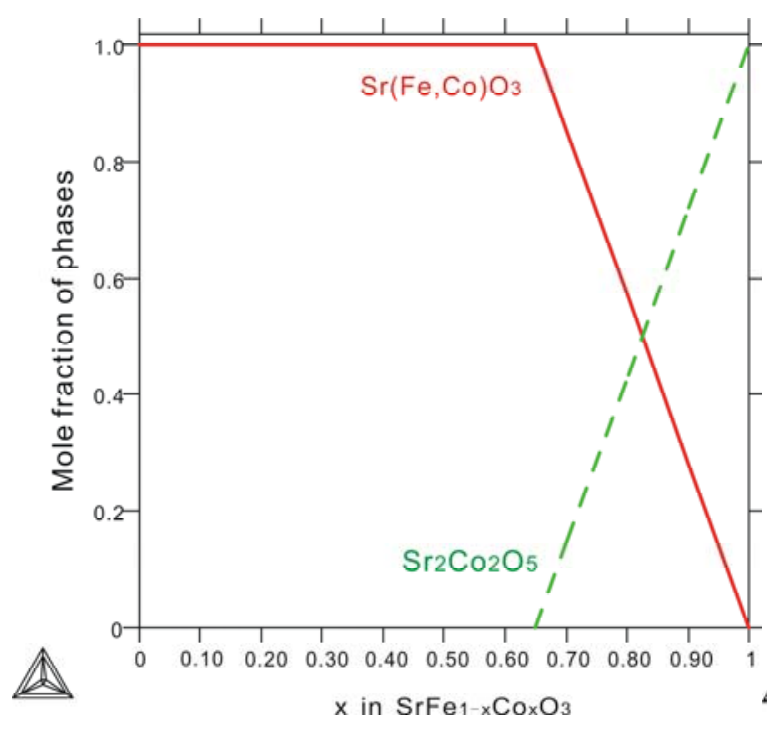

(a)

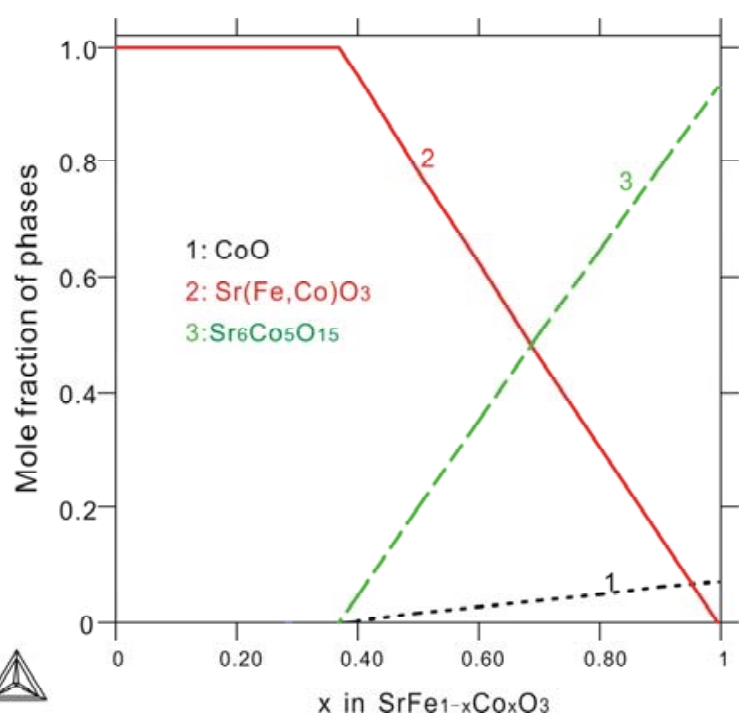

(b)

Fig. 7. Calculated phase fraction for the composition $\mathrm{SrFe}_{1-x} \mathrm{Co}_{x} \mathrm{O}_{3-\delta}$ in air, (a) at $1273 \mathrm{~K}$ and (b) $973 \mathrm{~K}$.

Table 4 Co solubility $\left(x\right.$ in $\left.\mathrm{Sr}_{4} \mathrm{Fe}_{6-x} \mathrm{Co}_{x} \mathrm{O}_{13}\right)$ at different temperatures in air

\begin{tabular}{cccc}
\hline T & $\begin{array}{c}\text { Calculated solubility from } \\
\text { this research }(x)\end{array}$ & $\begin{array}{c}\text { Experimentally determined } \\
\text { solubility }\end{array}$ & \\
\hline 1123 & 1.1 & 1 & {$[40]$} \\
1173 & 1.2 & 1.5 & {$[40]$} \\
1223 & 1.3 & 2 & {$[40]$} \\
1273 & 1.4 & 1.5 & {$[40,53]$} \\
& & 1.8 & {$[40]$} \\
1373 & 1.6 & 1.6 & {$[34]$} \\
& & 1 & {$[40]$} \\
1423 & 1.6 & 1.4 & {$[54]$} \\
1473 & 1.7 & 1.5 & {$[52]$} \\
\hline
\end{tabular}

As for the $\mathrm{SrFe}_{1-x} \mathrm{Co}_{x} \mathrm{O}_{3}$ perovskite, the cation valences (especially the B-site cations) have a significant influence on the magnetic property, electronic conductivity and thermal-conductivity of the perovskite. Fig. 8 presents the site fractions in $\mathrm{SrCo}_{0.2} \mathrm{Fe}_{0.8} \mathrm{O}_{3-\delta}$ in air as a function of temperature calculated in this research. Co and Fe exist mainly as cations with a valency of $4+$ or $3+$ in $\mathrm{SrCo}_{0.2} \mathrm{Fe}_{0.8} \mathrm{O}_{3-\delta}$ in air, which is in agreement with 
experimental results $[18,20]$. With increasing temperature, the concentration of $\mathrm{Co}^{3+}$ and of $\mathrm{Fe}^{3+}$ increases at the expense of a decrease in the concentration of $\mathrm{Co}^{4+}$ and $\mathrm{Fe}^{4+}$.

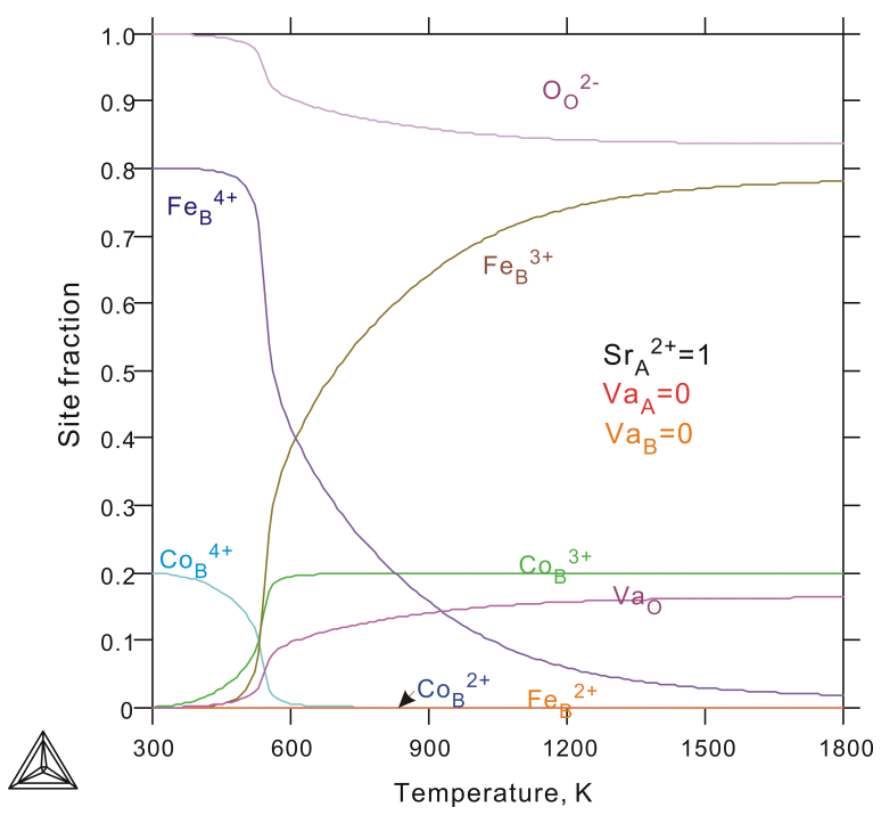

Fig. 8. Calculated site fractions in $\mathrm{SrCo}_{0.2} \mathrm{Fe}_{0.8} \mathrm{O}_{3-\delta}$ in air as a function of temperature.

\section{Conclusions}

As a part of a research project aimed at developing a thermodynamic database of the La-Sr-Fe-Co-O system for applications in SOFCs and gas permeation membranes, thermodynamic databases for the Sr-Co-O and SrCo-Fe-O systems were developed by applying the CALPHAD method. The resulting database can be used for calculating phase equilibria and thermodynamic properties at temperatures of $298-3000 \mathrm{~K}$ and oxygen partial pressure of $10^{-15}-1$ bar using Gibbs energy minimization software. Despite scarce experimental data for some of the occurring phases, the assessed thermodynamics of the perovskite phase allows for some important predictions: In Sr-Co-O, the perovskite phase is stable only at high temperatures; In $\mathrm{Sr}-\mathrm{Co}-\mathrm{Fe}-\mathrm{O}$, at $T \leq 1373 \mathrm{~K}$, the perovskite phase is stable with high Fe content and its stability decreases with decreasing temperature.

\section{Acknowledgment}

The financial support from HyFC - The Danish Hydrogen and Fuel Cell Academy and Topsoe Fuel Cell A/S is gratefully acknowledged. The authors would also like to thank Dr. James E. Saal and Prof. Zi-Kui Liu for providing thermodynamic database for discussion.

\section{References}

[1] L. Qiu, T.H. Lee, L.-M. Liu, Y.L. Yang, A.J. Jacobson, Solid State Ionics 76 (1995) 321-329.

[2] G.M. Veith, R. Chen, G. Popov, M. Croft, Y. Shokh, I. Nowik, M. Greenblatt, J. Solid State Chem. 166 (2002) 292-304.

[3] S. Ghosh, P. Adler, J. Mater. Chem. 12 (2002) 511-521. 
[4] M.V. Zinkevich, V.V. Vashchuk, Sov. Electrochem. 28 (1992) 1481-1485.

[5] D. Gostovic, J.R. Smith, D.P. Kundinger, K.S. Jones, E.D. Wachsman, Electrochem. Solid-State Lett. 10 (2007) B214-B217.

[6] D. Beckel, U.P. Muecke, T. Gyger, G. Florey, A. Infortuna, L.J. Gauckler, Solid State Ionics 178 (2007) 407-415.

[7] G. DiGiuseppe, L. Sun, Int. J. Hydrogen Energy 36 (2011) 5076-5087.

[8] E. Povoden-Karadeniz, unpublished work, http://wwwt.tuwien.ac.at/fileadmin/t/wwwt/forschung/wt/Pro jekte/ Erwin_Povoden-Karadeniz_neu/LSF.TDB.

[9] D. Risold, B. Hallstedt, L.J. Gauckler, CALPHAD 20 (1996) 353-361.

[10] M. Chen, B. Hallstedt, L.J. Gauckler, J. Phase Equilib. 24 (2003) 212-227.

[11] B. Sundman, J. Phase Equilib. 12 (1991) 127-140.

[12] W.-W Zhang, M. Chen, CALPHAD 41 (2013) 76-88.

[13] Y. Takeda, R. Kanno, T. Takada, O. Yamamoto, M. Takano, Y. Bando, Z. Anorg. Allg. Chem. 540/541 (1986) 259-270.

[14] J. Rodriguez, J.M. Gonzalez-Calbet, J.C. Grenier, J. Pannetier, M. Anne, Solid State Commun. 62 (1987) 231-234.

[15] W.T.A. Harrison, S.L. Hegwood, A.J. Jacobson, J. Chem. Soc. Chem. Commun. (1995) 1953-1954.

[16] V.V. Vashook, M.V. Zinkevich, Y.G. Zonov, Solid State Ionics 116 (1999) 129-138.

[17] V.V. Vashook, M.V. Zinkevich, H. Ullmann, J. Paulsen, N. Trofimenko, K. Teske, Solid State Ionics 99 (1997) 23-32.

[18] H. Taguchi, M. Shimada, M. Koizumi, J. Solid State Chem. 29 (1979) 221-225.

[19] H. Taguchi, M. Shimada, M. Koizumi, Mater. Res. Bull. 15 (1980) 165-169.

[20] A. Nakatsuka, A. Yoshiasa, N. Nakayama, T. Mizota, H. Takei. Acta Cryst. C60 (2004) i59-i60.

[21] V.V. Vashuk, S.A. Prodan, M.V. Zinkevich, O.P. Ol'shevskaya, Inorg. Mater. 29 (1993) 730-734.

[22] R.L. Toquin, W. Paulus, A. Cousson, C. Prestipino, C. Lamberti, J. Am. Chem. Soc. 128 (2006) 1316113174.

[23] F. Calle-Vallejo, J.I. Martínez, J.M. García-Lastra, M. Mogensen, J. Rossmeisl, Angew. Chem. Int. Ed. 49 (2010) 7699-7701.

[24] J.-C. Grenier, S. Ghodbane, G. Demazeau, Mater. Res. Bull. 14 (1979) 831-839.

[25] J.E. Saal, PhD thesis, Pennsylvania State University, 2010.

[26] J. Rodríguez, J.M. González-Calbet, Mater. Res. Bull. 21 (1986) 429-439.

[27] P.D. Battle, T.C. Gibb, A.T. Steel, J. Chem. Soc. Dalton Trans. (1987) 2359-2363.

[28] J.L. Sun, G.B. Li, Z.F. Li, L.P. You, J.H. Lin, Inorg. Chem. 45 (2006) 8394-8402.

[29] K. Iwasaki, T. Ito, T. Matsui, T. Nagasaki, S. Ohta, K. Koumoto, Mater. Res. Bull. 41 (2006) 732-739.

[30] J.E. Saal, Y. Wang, S. Shang, Z.-K. Liu, Inorg. Chem. 49 (2010) 10291-10298.

[31] O. Gourdon, V. Petricek, M. Dusek, P. Bezdicka, S. Durovic, D. Gyepesova, M. Evain, Acta Cryst. B55 (1999) 841-848.

[32] K. Li, D. Sheptyakov, Y. Wang, C.-K. Loong, J. Lin, J. Solid State Chem. 184 (2011) 888-892.

[33] W. Wong-Ng, G. Liu, J. Martin, E.L. Thomas, N. Lowhorn, J.A. Kaduk, J. Appl. Phys. 107 (2010) 033508.

[34] T.V. Aksenova, L.Ya. Gavrilova, V.A. Cherepanov, J. Solid State Chem. 181 (2008) 1480-1484.

[35] S.E. Dann, M.T. Weller, J. Solid State Chem. 115 (1995) 499-507.

[36] D. Pelloquin, N. Barrier, A. Maignan, V. Caignaert, Solid State Sci. 7 (2005) 853-860.

[37] J.M. Hill, B. Dabrowski, J.F. Mitchell, J.D. Jorgensen, Phys. Rev. B 74 (2006) 174417.

[38] L. Viciu, H.W. Zandbergen, Q. Xu, Q. Huang, M. Lee, R.J. Cava, J. Solid State Chem. 179 (2006) 500-

511.

[39] X.L. Wang, H. Sakurai, E. Takayama-Muromachi, J. Appl. Phys. 97 (2005) 10M519.

[40] A. Fossdal, L.T. Sagdahl, M.A. Einarsrud, K. Wiik, T. Grande, P.H. Larsen, F.W. Poulsen, Solid State Ionics 143 (2001) 367-377. 
[41] L.V. Kokhanovskii, Y.G. Zonov, O.P. Ol'shevskaya, V.V. Pan'kov, Inorg. Mater. 41 (2005) 876-881.

[42] L.V. Kokhanovskii, V.V. Vashuk, O.P. Ol'shevskaya, O.I. Kirilenko, Inorg. Mater. 37 (2001) 730-736.

[43] L.M. Liu, T.H. Lee, L. Qiu, Y.L. Yang, A.J. Jacobson, Mater. Res. Bull. 31 (1996) 29-35.

[44] N. Grunbaum, L. Mogni, F. Prado, A. Caneiro, J. Solid State Chem. 177 (2004) 2350-2357.

[45] S. McIntosh, J.F. Vente, W.G. Haije, D.H.A. Blank, H.J.M. Bouwmeester, Solid State Ionics 177 (2006) 833-842.

[46] S. McIntosh, J.F. Vente, W.G. Haije, D.H.A. Blank, H.J.M. Bouwmeester, Solid State Ionics 177 (2006) 1737-1742.

[47] B.J. Mitchell, R.C. Rogan, J.W. Richardson Jr., B. Ma, U. Balachandran, Solid State Ionics 146 (2002) 313-321.

[48] V.V. Vashuk, L.V. Kokhanovskii, I.I. Yushkevich, Inorg. Mater. 36 (2000) 1043-1049.

[49] H. Fjellvåg, B. C. Hauback, R. Bredesen, J. Mater. Chem. 7 (1997) 2415-2419.

[50] Y. Xia, T. Armstrong, F. Prado, A. Manthiram, Solid State Ionics 130 (2000) 81-90.

[51] B. Ma, J.P. Hodges, J.D. Jorgensen, D.J. Miller, J.W. Richardson, U. Balachandran, J. Solid State Chem. 141 (1998) 576-586.

[52] Z.-Q. Deng, G.-G. Zhang, W. Liu, D.-K. Peng, C.-S. Chen, Solid State Ionics 152-153 (2002) 735-739.

[53] T. Armstrong, E. Prado, Y. Xia, A. Manthiram, J. Electrochem. Soc. 147 (2000) 435-438.

[54] S. Kim, Y.L. Yang, R. Christoffersen, A.J. Jacobson, Solid State Ionics 109 (1998) 187-196.

[55] M. Hillert, J. Alloys Compd. 320 (2001) 161-176.

[56] A.T. Dinsdale, CALPHAD 15 (1991) 317-425.

[57] M. Hillert, B. Jansson, B. Sundman, J. Ågren, Metall. Trans. 16A (1985) 261-266.

[58] B. Sundman, CALPHAD 15 109-119(1991).

[59] W.-W Zhang, M. Chen, E. Povoden-Karadeniz, P. V. Hendriksen, submitted to J. Phase Equilib. Diff.

[60] A.N. Grundy, B. Hallstedt, L.J. Gauckler, J. Phase Equilib. Diff. 25 (2004) 311-319.

[61] A.N. Grundy, M. Chen, B. Hallstedt, L.J. Gauckler, J. Phase Equilib. Diff. 26 (2005) 131-151.

[62] E. Povoden, M. Chen, A.N. Grundy, T. Ivas, L.J. Gauckler, J. Phase Equilib. Diff. 30 (2009) 12-27.

[63] E. Povoden-Karadeniz, M. Chen, T. Ivas, A.N. Grundy, L.J. Gauckler, J. Mater. Res. 27 (2012) 19151926.

[64] B. Sundman, B. Jansson, J.-O. Andersson, CALPHAD 9 (1985) 153-190.

[65] V.A. Cherepanov, L.Ya. Gavrilova, L.Yu. Barkhatova, V.I. Voronin, M.V. Trifonova, O.A. Bukhner, Ionics 4 (1998) 309-315. 